\title{
Modern deep-water agglutinated foraminifera from IODP Expedition 323, Bering Sea: ecological and taxonomic implications
}

\author{
Sev Kender ${ }^{1,2 *}$ \& Michael A. Kaminski ${ }^{3}$ \\ ${ }^{1}$ Centre for Environmental Geochemistry, School of Geography, University of Nottingham, University Park, Nottingham NG7 \\ 2RD, UK \\ ${ }^{2}$ British Geological Survey, Environmental Sciences Centre, Keyworth, Nottingham NG12 5GG, UK \\ ${ }^{3}$ Geosciences Department, King Fahd University of Petroleum and Minerals, PO Box 701, Dhahran, 21361, Saudi Arabia \\ *Correspondence: sev.kender@nottingham.ac.uk
}

\begin{abstract}
Despite the importance of the Bering Sea for subarctic oceanography and climate, relatively little is known of the foraminifera from the extensive Aleutian Basin. We report the occurrence of modern deep-water agglutinated foraminifera collected at seven sites cored during Integrated Ocean Drilling Program (IODP) Expedition 323 in the Bering Sea. Assemblages collected from core-top samples contained 32 genera and 50 species and are described and illustrated here for the first time. Commonly occurring species include typical deep-water Rhizammina, Reophax, Rhabdammina, Recurvoides and Nodulina. Assemblages from the northern sites also consist of accessory Cyclammina, Eggerelloides and Glaphyrammina, whilst those of the Bowers Ridge sites consist of other tubular genera and Martinottiella. Of the studied stations with the lowest dissolved oxygen concentrations, the potentially Bering Sea endemic Eggerelloides sp. 1 inhabits the northern slope, which has the highest primary productivity, and the potentially endemic Martinottiella sp. 3 inhabits Bowers Ridge, which has the lowest oxygen concentrations but relatively low annual productivity. Martinottiella sp. 3, with open pores on its test surface, has previously been reported in Pliocene to Recent material from Bowers Ridge. Despite relatively small sample sizes, ecological constraints may imply that the Bering Sea experienced high productivity and reduced oxygen at times since at least the Pliocene. We note the partially endemic nature of the agglutinated foraminiferal assemblages, which may at least in part be due to basin restriction, the geologically long time period of reduced oxygen, and high organic carbon flux. Our results indicate the importance of gathering further surface sample data from the Aleutian Basin.
\end{abstract}

Keywords: deep-water agglutinated foraminifera, Bering Sea, modern ecology, productivity, oxygen minimum zone

Received 15 July 2016; revised 30 July 2016; accepted 31 July 2016

The Bering Sea extends over a region comparable in size to the Mediterranean, yet the modern agglutinated foraminifera are still virtually unstudied. The interaction of strong currents, upwelling high nutrient water masses, sea ice and strong winds causes high surface water productivity which supports a diverse ecosystem (Stabeno et al. 1999) and an expanded oxygen minimum zone (OMZ). Relatively recent palaeoceanographic work indicates that the Bering Sea may have been characterized by high productivity and low oxygen since at least the Pliocene (Expedition 323 Scientists 2011; Kaminski et al. 2013) and, therefore, is an ideal place to study the long-term impact of severe hypoxia and high organic carbon flux on benthic organisms, in particular the less well-studied agglutinated foraminifera which are a diverse group particularly tolerant to ocean acidification due to their noncalcareous tests. Observational studies have recorded an expansion of tropical OMZs in the Pacific Ocean and Atlantic Ocean over the last 60 years, which is likely to continue with future increased atmospheric $\mathrm{CO}_{2}$ emissions and oceanic sequestration (Stramma et al. 2008, 2010; Hofmann \& Schellnhuber 2009). Studies of OMZ benthic ecology are, therefore, of particular interest (Gooday \& Jorissen 2012). Although there have been several studies of modern benthic foraminifera from within OMZs world-wide (e.g. Hermelin \& Shimmield 1990; Sen Gupta \& Machain-Castillo 1993; Kaminski et al. 1995; Kaiho 1999; Gooday et al. 2000; Schumacher et al. 2007), there remains a lack of information from the Bering Sea.

On account of the Bering Sea's high sedimentation rate along the slope, restricted deep-water circulation, low oxygen conditions and its partial isolation from the Pacific by the Aleutian Islands volcanic arc, the Bering Sea slope sites may be a good modern analogue to the type of high sedimentation-rate deep-sea environments in the Cretaceous to Palaeogene Alpine-Carpathian and North Atlantic basins containing rapidly deposited orogenic-derived sediments called flysch. Under such conditions agglutinated foraminifera are an extremely important component of the benthic fauna, and fossil assemblages from the flysch basins are often comprised exclusively of agglutinated benthic foraminifera (e.g. Gradstein \& Berggren 1981; Kender et al. 2005; Waskowska-Oliwa 2008; Setoyama et al. 2011).

In this study we fully document the agglutinated foraminifera in the deep ( $>800 \mathrm{~m}$ water depth) Bering Sea, in order to assess the degree of endemism in this restricted basin and to assess the possible ecological controls on agglutinated foraminiferal abundance.

\section{Bering Sea oceanography}

Approximately half of the modern Bering Sea comprises a shallow $(0-200 \mathrm{~m})$ neritic environment, the remainder a vast plain $c .4 \mathrm{~km}$ deep broken by the Bowers and Shirshov ridges (Fig. 1). The northern continental shelf is covered seasonally by sea ice, with little ice presently being formed over the deep SW areas. The Bering Sea is one of the most highly biologically productive regions in the world, exporting some 687000 tons of carbon per year (Sambrotto et al. 1984; Stabeno et al. 1999). 'Old' deep water, characterized by low oxygen concentrations, high nutrients (e.g. phosphate and nitrate) and high dissolved $\mathrm{CO}_{2}$, flows into the Bering Sea at depth from the North Pacific. It cycles counter-clockwise around the Bering Sea Basin, upwelling particularly over the continental shelf feeding the so-called 'Green Belt' (Springer et al. 1996). As large 


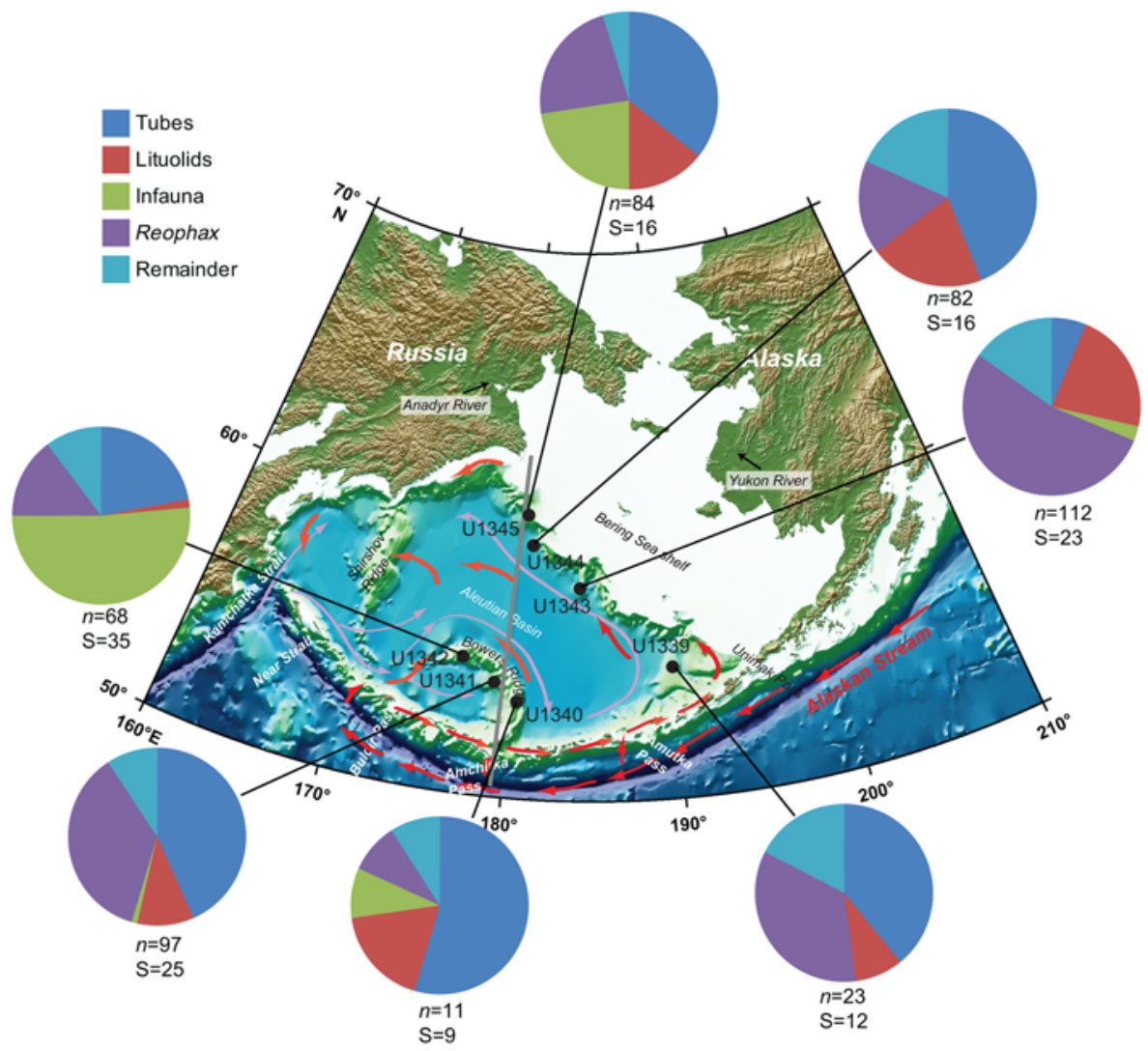

Fig. 1. Bathymetric map of the Bering Sea (Expedition 323 Scientists 2010), showing IODP Expedition 323 sites reported in this study, and the number of specimens $(n)$ and number of taxa (S) in major agglutinated foraminiferal assemblage components from core-top samples. Also indicated are the major surface (red arrows) and deep (purple arrows) ocean currents. Grey line corresponds to the section shown in Figure 3. fluxes of organic carbon make their way to the seafloor in parts of the Bering Sea, particularly along the slope and over the shelf in spring (Fig. 2), intense oxygen demand expands the OMZ (Fig. 3), which impacts the composition of benthic foraminiferal communities and the chemistry of ocean water (Expedition 323 Scientists 2011). Significant exchange of Pacific deep water occurs through the Kamchatka Strait (maximum depth of $4420 \mathrm{~m}$ ), and of low oxygen intermediate water through the Commander-Near Strait at $2000 \mathrm{~m}$ (Coachman et al. 1999). Very small amounts of bottom water are formed in the Bering Sea today (Warner \& Roden 1995) and, as a result, the deep Bering Sea has an expanded OMZ in comparison with the northern Pacific.

\section{Previous studies of benthic foraminifera}

Modern benthic foraminifera have been reported from Rose Bengalstained core-top samples collected on the Bering Sea shelf at water depths less than $200 \mathrm{~m}$ (Anderson 1963). This study reported the occurrence of agglutinated foraminifera, which sometimes dominate the foraminiferal assemblages in the deeper shelf basins. Anderson (1963) reported that the proportion of agglutinated foraminifera may reach $90 \%$ of the total foraminiferal fauna on the central Bering Sea shelf. However, the modern deep-water agglutinated foraminifera from the deeper Aleutian Basin, within and below the OMZ, have yet to be documented. Khusid et al. (2006) studied the benthic foraminifera from a $660 \mathrm{~cm}$ long core collected at $3060 \mathrm{~m}$ depth on Bowers Ridge. In this core, the agglutinated foraminifera were found mainly in the core top and to a depth of $20 \mathrm{~cm}$. The late Holocene agglutinated foraminifera comprised $83-99 \%$ of the fauna at this location, and consisted of Rhabdammina, Hormosina, Ammolagena, Cribrostomoides and Karreriella. However, neither Anderson (1963) nor Khusid et al. (2006) provided any descriptions or illustrations of the agglutinated foraminifera.

The agglutinated foraminifera from the North Pacific and Siberian Arctic have been more intensively studied than the fauna from the Bering Sea. In this study we made use of the taxonomic monographs of Cushman (1910, 1921), Saidova (1975), Matoba \& Fukusawa (1992) and Zheng \& Fu (2001) on North Pacific foraminifera; the work of Vázquez Riveiros \& Patterson (2007) on the foraminifera from the North Pacific Fjords; as well as studies on Arctic foraminifera by Cushman (1944), Wollenburg (1992, 1995) and Lukina (2001). The distribution of foraminifera along the North Pacific continental margins was compiled by Culver \& Buzas (1985, 1987). Szarek (2001, unpublished PhD thesis, 'Biodiversity and biogeography of recent benthic foraminiferal assemblages in the south-western South China Sea (Sunda Shelf)', ChristianAlbrechts University, Kiel) provides an excellent taxonomic section and useful distributional data for Bering Sea fauna Reophax bradyi and $R$. oviculus in the South China Sea. The current study aims to bridge a geographical gap in our knowledge of the distribution of North Pacific-Arctic agglutinated foraminifera, by providing descriptions of species recovered from the IODP Expedition 323 coring sites.

\section{Methods and materials}

Samples were collected and prepared on board the JOIDES Resolution drillship from each site (U1339-45) during IODP Expedition 323, Bering Sea, in June/July 2009. Samples (quantities of sediment) were collected from the first cores recovered at each new hole (typically several holes were cored at each IODP site, within a distance of $<20 \mathrm{~m}$ ), by emptying the core barrel of unconsolidated core-top sediment into a cleaned receptacle. Samples ranged widely in size, but were generally $>100 \mathrm{~g}$ in weight. Sediment composition varied between sites, but was varyingly dominated by diatoms and fine clays and silts with only rare coarser sand-sized particles. Two samples were then immediately stained in a Rose Bengal solution for $>24 \mathrm{~h}$ to ascertain the living component. Samples were carefully washed over a $>63 \mu \mathrm{m}$ mesh sieve with deionized water. Sample residues were oven dried at $<40^{\circ} \mathrm{C}$ and agglutinated foraminifera picked out and placed in 


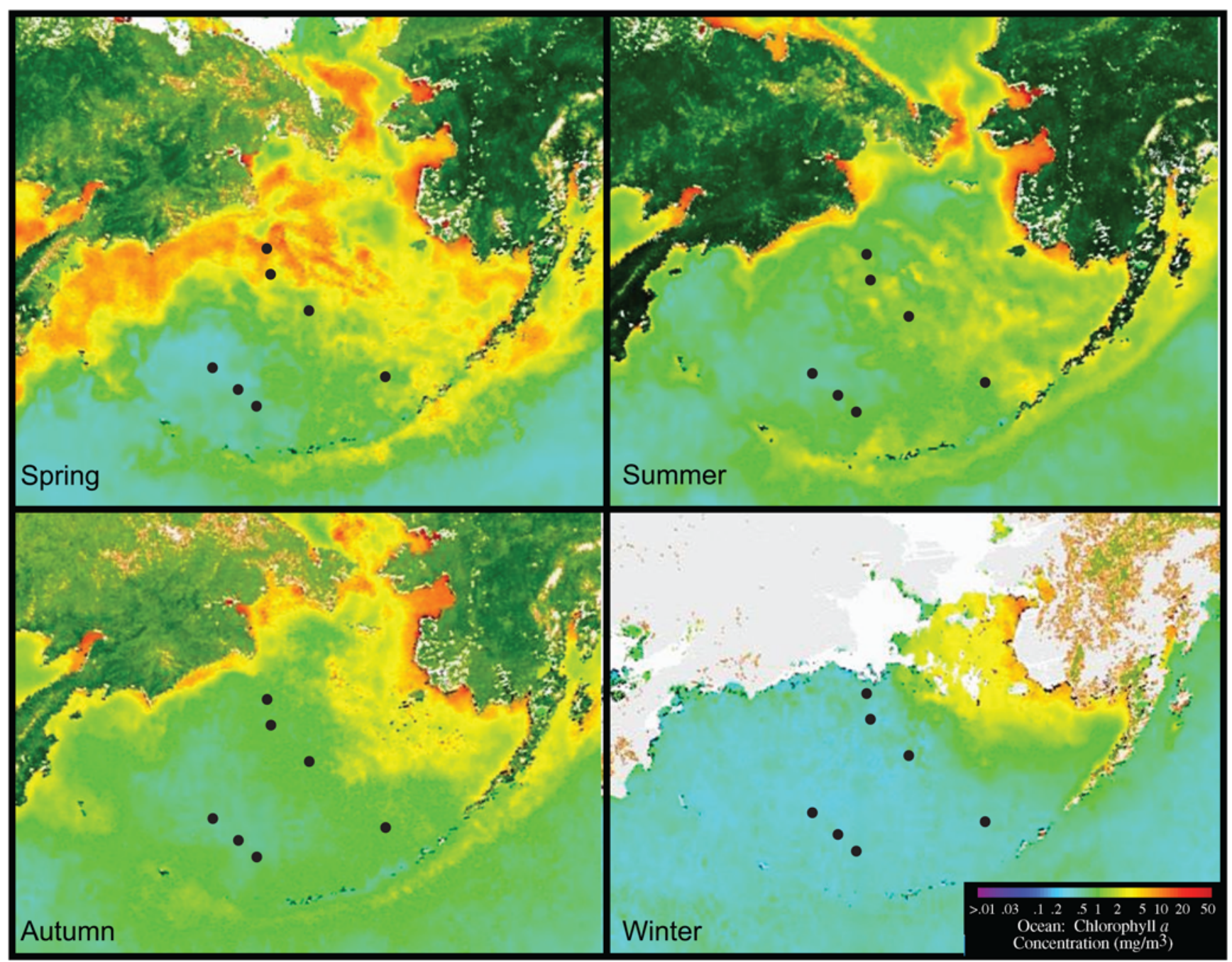

Fig. 2. Seasonal estimates from the years 1998-2003 of oceanic chlorophyll- $a$ concentration $\left(\mathrm{mg} \mathrm{m}^{-3}\right.$ ) from satellite imagery SeaWiFS (http://oceancolor. gsfc.nasa.gov/SeaWiFS). Also shown are the positions of the seven IODP Expedition 323 sites (see Fig. 1 for labels).

cardboard reference slides. Specimens were imaged using a JSM5900LV SEM at King Fahd University of Petroleum and Minerals in Dhahran, and a LEO 535VP SEM at the British Geological Survey in Keyworth. The proportion of faunal groups shown in Figure 1 was calculated for each site by combining the faunal counts of all samples from that site. Correspondence Analysis (CA), a reciprocal averaging algorithm, was carried out (using the software of Hammer et al. 2005) on the dataset to statistically ascertain the relationships between samples, species and selected environmental parameters (Figs 4 and 5), as described in Hammer \& Harper (2006). CA in

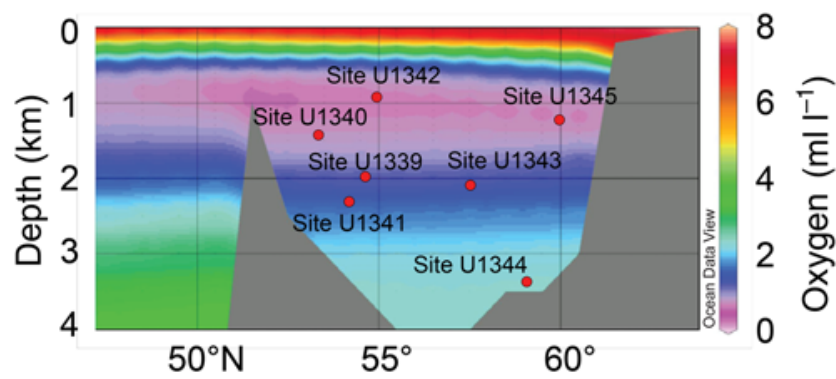

Fig. 3. Bering Sea north-south section (see approximate line in Fig. 1; Bowers Ridge not shown here) showing dissolved oxygen concentrations $\left(\mathrm{ml}^{-1}\right.$; Schlitzer 2000) and the position of IODP Expedition 323 sites analysed in this study (Expedition 323 Scientists 2010).
Figure 4 was carried out on a modified dataset, in order to incorporate environmental information with widely varying numerical values compared to species counts. Species counts were summed for each site and Site U1340 was removed because of low counts. Species that had an occurrence of $<10$ in the total dataset were removed to avoid artificially placing emphasis on low counts. The amount of dissolved bottom water oxygen (estimated from World Ocean Circulation Experiment data, Fig. 3) and spring primary productivity (estimated from satellite chlorophyll- $a$ data, Fig. 2) was recorded for each site (Table 1) and included in CA. All species counts and environmental parameters were subsequently normalized, and 2 added to each value to lift all numerical values above 0 (a requirement for CA). CA in Figure 5 was carried out on an unmodified dataset of all samples separately, in order to ascertain the degree of similarity between samples of different sites.

\section{Results}

A total of 524 specimens of agglutinated benthic foraminifera were recorded, identified and described from 19 core-top samples taken at all seven IODP Expedition 323 sites (Figs 1 and 4; Table 2). The samples were dominated by calcareous benthic foraminifera, which were reported by Expedition 323 Scientists (2011) and reproduced in Table 3. Preservation of agglutinated taxa is generally excellent (see Figs 6-10), which is in marked contrast to the agglutinatedpoor Pliocene-Recent palaeontological assemblages recovered 


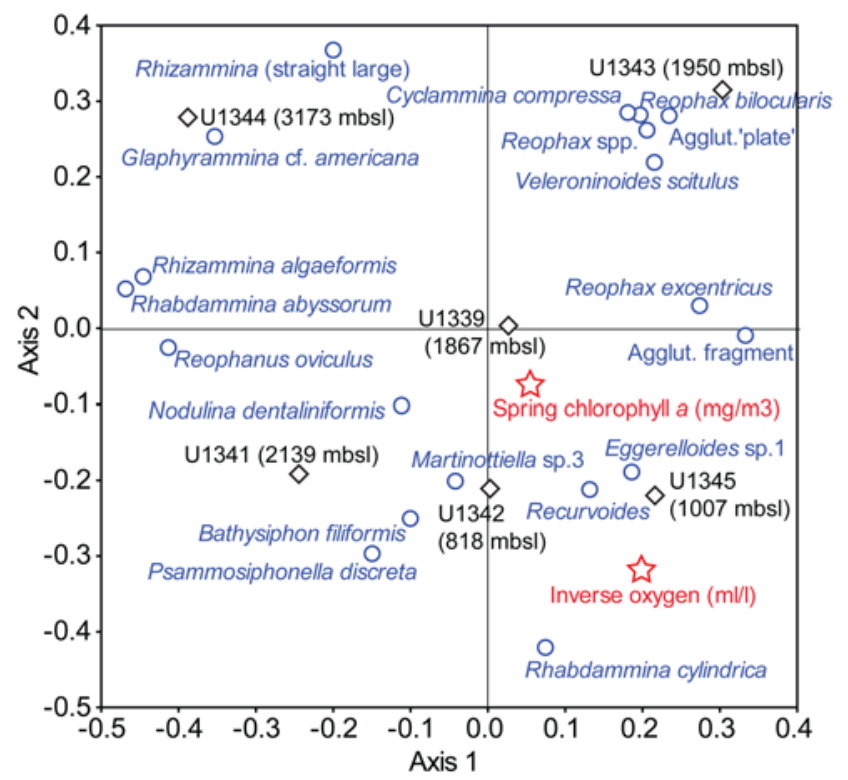

Fig. 4. Correspondence Analysis (CA) for dataset (including chlorophyll and inverse oxygen estimates; stars), showing species (circles) and sample (diamonds) scores for axis 1 against axis 2 . Bottom water oxygen values were inverted, so that proximal species and samples exhibit low oxygen. Only species with $>10$ specimens are included (see 'Methods' for further details of data analysis). Mbsl, metres below sea-level.

from down-core samples (Expedition 323 Scientists 2011; Kaminski et al. 2013), indicating post-mortem dissolution of the organic cement likely occurred. Abundance is $>70$ specimens at most sites, apart from Sites U1339 and U1340 where abundances are low due to the small volume of core-top samples collected. CA (Fig. 5) indicates that there is generally greater similarity between samples from one site than between samples from different sites, as

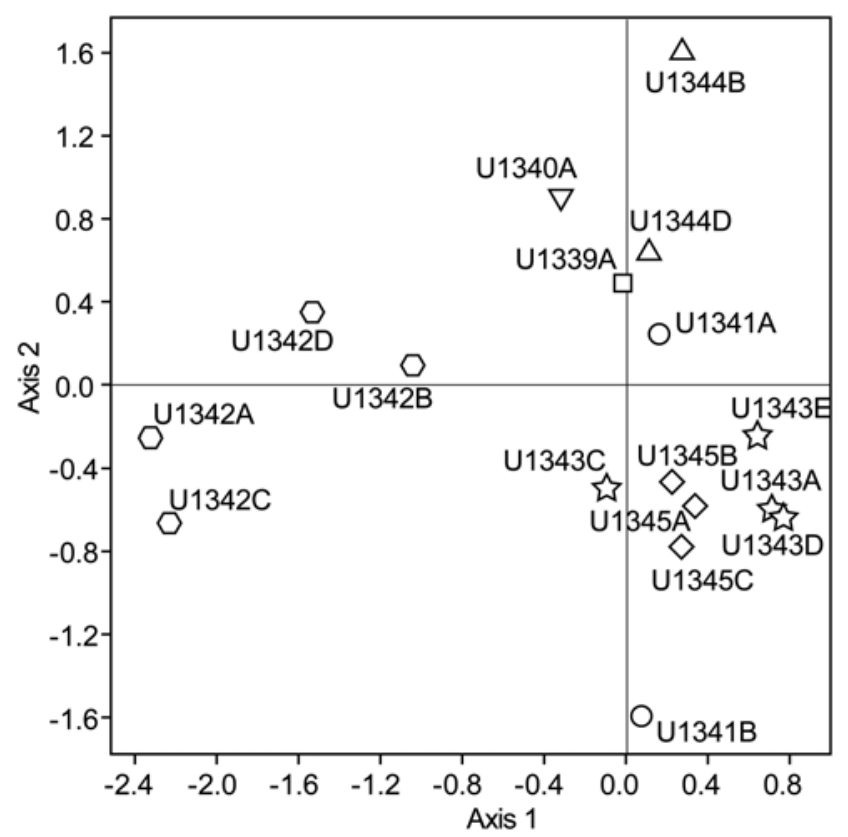

Fig. 5. Correspondence Analysis (CA) for dataset, showing sample scores for axis 1 against axis 2. Samples plotting close together exhibit similar species compositions. The majority of samples plot close to other samples from the same site, showing the distinctiveness of assemblages from each site. Samples U1341B, U1343C and U1343D have very low abundances, explaining why they plot further away from the other samples of those two sites. the majority of samples cluster near those of the same site. Samples U1341B and U1343C plot further away, which can be explained by their particularly low abundances (see Table 2). The generally lowdiversity agglutinated assemblages $(9-35$ taxa per site) are predominantly composed of tubular suspension-feeders (e.g. Rhabdammina, Rhizammina and Bathysiphon), epifaunal lituolids (e.g. Recurvoides, Cyclammina), opportunistic infauna (e.g. Reophax and Hormosinella) and infauna (e.g. Eggerelloides and Martinottiella) in varying proportions (Fig. 1). CA indicates that some species are more prevalent at certain sites (i.e. plot in close proximity on Fig. 4); that Sites U1339, U1342 and U1345 are most associated with high chlorophyll- $a$ concentrations (a proxy for primary productivity); and that Sites U1342 and U1345 are most associated with low bottom water dissolved oxygen. Two samples were stained with Rose Bengal (at Sites U1342 and U1345). These samples contained a small proportion of living individuals (Table 2), confirming that the IODP cores recovered samples of modern/sub-modern age.

\section{Discussion}

\section{Endemism}

Although a sizeable proportion of Bering Sea agglutinated foraminifera have been recorded in the Pacific Ocean (Jones 1994), there are several species in the core-top samples (this study) and in the Pliocene (Kaminski et al. 2013) that appear to be endemic (e.g. Eggerelloides sp. 1; Glaphyrammina cf. americana; Martinottiella sp. 1; Martinottiella sp. 2; Martinottiella sp. 3; Karreriella sp. 1; Bathysiphon sp., Hormosinelloides sp.) and confirm the semi-isolated nature of the microfauna in the Bering Sea. Of the 131 agglutinated species recorded by Culver \& Buzas (1985) from the North Pacific Margin (at 138 localities) only 13 are present in our samples. This low number of species in common suggests that many taxa present along the Alaskan margin are excluded from our study locations in the Bering Sea. In our current study of the agglutinated foraminifera, $22 \%$ of the species are left in open nomenclature and do not yet appear to have been described. In the Pleistocene calcareous benthic assemblage studied by Setoyama \& Kaminski (2015) at Site 1341, 23\% of the taxa were identified tentatively or left in open nomenclature. In contrast Culver \& Buzas (1985) reported only a few species in open nomenclature. Geographical barriers for faunal interchange between the Bering Sea and North Pacific include the restricted Aleutian passes (Fig. 1), although the western passes are deep $(>4 \mathrm{~km})$ and the majority of Bering Sea benthic species recorded in our study are cosmopolitan. It is therefore possible that environmental conditions in the isolated Bering Sea, such as high productivity and reduced bottom water oxygen, have allowed for the adaptation of certain new species or varieties.

Considering the long stratigraphic ranges of the majority of benthic foraminifera (e.g. Kaminski \& Gradstein 2005; Holbourn et al. 2013), and their relatively slow genetic evolution compared with planktonics (Pawlowski et al. 1997; Gooday \& Jorissen 2012), the occurrence of endemic species is consistent with a Bering Sea that may have been isolated for a considerable length of time. This is not unique for semi-isolated deep-water basins, and one such example is the high-latitude Norwegian Sea during the Eocene, when it was separated from the North Atlantic by the GreenlandScotland Ridge. The deep-water agglutinated foraminiferal assemblages that developed during the Eocene and Oligocene in this basin contain a number of endemic species that have not been found in the northern Atlantic (Gradstein \& Kaminski 1989; Kaminski \& Gradstein 2005). The Oligocene deep-water agglutinated foraminiferal assemblage at Site $985 \mathrm{~A}$ on the Iceland Plateau contains $27 \%$ endemic species (Kaminski \& Austin 1999). Agglutinated 
Table 1. Location, water mass properties and average sedimentation rate data of the IODP Expedition 323 sites analysed in this study

\begin{tabular}{|c|c|c|c|c|c|c|c|c|c|}
\hline Site & Latitude & Longitude & $\begin{array}{l}\text { Water depth } \\
(\mathrm{mbsl})\end{array}$ & $\begin{array}{l}\text { Ave. sedimentation rate } \\
\left(\mathrm{cm} \mathrm{ka}^{-1}\right)\end{array}$ & $\begin{array}{l}\text { Estimated bottom water } \\
\text { oxygen }\left(\mathrm{ml} \mathrm{l}^{-1}\right)\end{array}$ & $\begin{array}{l}\text { Bottom water temp. } \\
\left({ }^{\circ} \mathrm{C}\right)\end{array}$ & $\begin{array}{l}\text { Bottom water salinity } \\
\text { (psu) }\end{array}$ & $\begin{array}{l}\text { Spring chlorophyll- } a \\
\left(\mathrm{mg} \mathrm{m}^{-3}\right)\end{array}$ & $\begin{array}{l}\text { Winter chlorophyll- } a \\
\left(\mathrm{mg} \mathrm{m}^{-3}\right)\end{array}$ \\
\hline 323-U1339A & $54^{\circ} 40.2001^{\prime} \mathrm{N}$ & $169^{\circ} 58.9017^{\prime} \mathrm{W}$ & 1866.7 & 28.0 & 1.1 & 2.0 & 34.7 & 2.00 & 0.60 \\
\hline 323-U1339D & $54^{\circ} 40.1891^{\prime} \mathrm{N}$ & $169^{\circ} 58.8909^{\prime} \mathrm{W}$ & 1868.1 & 28.0 & 1.1 & 2.0 & 34.7 & 2.00 & 0.60 \\
\hline 323-U1340A & $53^{\circ} 24.0008^{\prime} \mathrm{N}$ & $179^{\circ} 31.2973^{\prime} \mathrm{W}$ & 1294.7 & 14.5 & 0.7 & 2.5 & 34.4 & 0.70 & 0.37 \\
\hline 323-U1341A & $54^{\circ} 2.0025^{\prime} \mathrm{N}$ & $179^{\circ} 0.4999^{\prime} \mathrm{E}$ & 2139.6 & 14.5 & 1.5 & 1.9 & 34.7 & 0.50 & 0.37 \\
\hline 323-U1341B & $54^{\circ} 1.9984^{\prime} \mathrm{N}$ & $179^{\circ} 0.5171^{\prime} \mathrm{E}$ & 2139.6 & 14.5 & 1.5 & 1.9 & 34.7 & 0.50 & 0.37 \\
\hline 323-U1341C & $54^{\circ} 2.0010^{\prime} \mathrm{N}$ & $179^{\circ} 0.5390^{\prime} \mathrm{E}$ & 2139.6 & 14.5 & 1.5 & 1.9 & 34.7 & 0.50 & 0.37 \\
\hline 323-U1342A & $54^{\circ} 49.6987^{\prime} \mathrm{N}$ & $176^{\circ} 55.0027^{\prime} \mathrm{E}$ & 818.3 & 4.5 & 0.6 & 3.0 & 34.3 & 0.40 & 0.37 \\
\hline 323-U1342B & $54^{\circ} 49.7004^{\prime} \mathrm{N}$ & $176^{\circ} 55.0232^{\prime} \mathrm{E}$ & 818.9 & 4.5 & 0.6 & 3.0 & 34.3 & 0.40 & 0.37 \\
\hline 323-U1342C & $54^{\circ} 49.7017^{\prime} \mathrm{N}$ & $176^{\circ} 55.0232^{\prime} \mathrm{E}$ & 818.8 & 4.5 & 0.6 & 3.0 & 34.3 & 0.40 & 0.37 \\
\hline 323-U1342D & $54^{\circ} 49.6987^{\prime} \mathrm{N}$ & $176^{\circ} 55.0027^{\prime} \mathrm{E}$ & 818.2 & 4.5 & 0.6 & 3.0 & 34.3 & 0.40 & 0.37 \\
\hline 323-U1343A & $57^{\circ} 33.3993^{\prime} \mathrm{N}$ & $175^{\circ} 48.9659^{\prime} \mathrm{W}$ & 1950.9 & 35.0 & 1.2 & 2.0 & 34.7 & 1.40 & 0.39 \\
\hline 323-U1343B & $57^{\circ} 33.4156^{\prime} \mathrm{N}$ & $175^{\circ} 48.9951^{\prime} \mathrm{W}$ & 1950.9 & 35.0 & 1.2 & 2.0 & 34.7 & 1.40 & 0.39 \\
\hline 323-U1343C & $57^{\circ} 33.3982^{\prime} \mathrm{N}$ & $175^{\circ} 49.0275^{\prime} \mathrm{W}$ & 1952.6 & 35.0 & 1.2 & 2.0 & 34.7 & 1.40 & 0.39 \\
\hline 323-U1343D & $57^{\circ} 33.3817^{\prime} \mathrm{N}$ & $175^{\circ} 48.9971^{\prime} \mathrm{W}$ & 1954.1 & 35.0 & 1.2 & 2.0 & 34.7 & 1.40 & 0.39 \\
\hline 323-U1343E & $57^{\circ} 33.3814^{\prime} \mathrm{N}$ & $175^{\circ} 48.9974^{\prime} \mathrm{W}$ & 1956.0 & 35.0 & 1.2 & 2.0 & 34.7 & 1.40 & 0.39 \\
\hline 323-U1344A & $59^{\circ} 3.0005^{\prime} \mathrm{N}$ & $179^{\circ} 12.2011^{\prime} \mathrm{W}$ & 3171.8 & 45.0 & 2.3 & 1.7 & 34.7 & 3.50 & 0.40 \\
\hline 323-U1344B & $59^{\circ} 3.0112^{\prime} \mathrm{N}$ & $179^{\circ} 12.2051^{\prime} \mathrm{W}$ & 3173.0 & 45.0 & 2.3 & 1.7 & 34.7 & 3.50 & 0.40 \\
\hline 323-U1344C & $59^{\circ} 3.0116^{\prime} \mathrm{N}$ & $179^{\circ} 12.2052^{\prime} \mathrm{W}$ & 3172.7 & 45.0 & 2.3 & 1.7 & 34.7 & 3.50 & 0.40 \\
\hline 323-U1344D & $59^{\circ} 3.0224^{\prime} \mathrm{N}$ & $179^{\circ} 12.2030^{\prime} \mathrm{W}$ & 3174.1 & 45.0 & 2.3 & 1.7 & 34.7 & 3.50 & 0.40 \\
\hline 323-U1345A & $60^{\circ} 9.1917^{\prime} \mathrm{N}$ & $179^{\circ} 28.2036^{\prime} \mathrm{W}$ & 1007.4 & 29.0 & 0.6 & 2.5 & 34.4 & 8.00 & 0.50 \\
\hline 323-U1345B & $60^{\circ} 9.2003^{\prime} \mathrm{N}$ & $179^{\circ} 28.2127^{\prime} \mathrm{W}$ & 1007.5 & 29.0 & 0.6 & 2.5 & 34.4 & 8.00 & 0.50 \\
\hline 323-U1345C & $60^{\circ} 9.2097^{\prime} \mathrm{N}$ & $179^{\circ} 28.2229^{\prime} \mathrm{W}$ & 1008.8 & 29.0 & 0.6 & 2.5 & 34.4 & 8.00 & 0.50 \\
\hline 323-U1345D & $60^{\circ} 9.2175^{\prime} \mathrm{N}$ & $179^{\circ} 28.2283^{\prime} \mathrm{W}$ & 1008.3 & 29.0 & 0.6 & 2.5 & 34.4 & 8.00 & 0.50 \\
\hline
\end{tabular}

Expedition 323 Scientists (2010). Location, water mass properties are estimated from Figs 1, 2 and WOCE data 


\begin{tabular}{|c|c|c|c|c|c|c|c|c|c|c|c|c|c|c|c|c|c|c|c|}
\hline Species & U1339A & U1340A & U1341A & U1341B & U1342A & $\begin{array}{l}\text { U1342A- } \\
\text { stained }\end{array}$ & U1342B & U1342C & U1342D & U1343A & U1343C & U1343D & U1343E & U1344B & U1344D & U1345A & U1345B & $\begin{array}{l}\text { U1345B- } \\
\text { stained }\end{array}$ & U1345C \\
\hline Agglutinated fragments & 9 & 1 & 3 & 2 & 1 & & 1 & & 1 & 7 & & 5 & 9 & & & 9 & 3 & & 11 \\
\hline Ammodiscus sp. & & & 1 & & & & & & & & & & & & & & & & \\
\hline $\begin{array}{l}\text { Archimerismus } \\
\text { subnodosus }\end{array}$ & & & 2 & & & & 1 & & & & & & & 4 & & & & & 2 \\
\hline Astrorhiza granosa & & & & & & & & & & & & & & & & & 1 & & \\
\hline Bathysiphon filiformis & & & 7 & & & & & & & 1 & & & & & & 1 & & & 3 \\
\hline $\begin{array}{l}\text { Bathysiphon sp. } \\
\text { 'coarse' }\end{array}$ & & & 3 & & & & & & & & & & & & & & & & \\
\hline $\begin{array}{l}\text { Cribrostomoides } \\
\text { subglobosus }\end{array}$ & & & & & & & & & & & 1 & & & & & & & & \\
\hline Cyclammina compressa & & & & & & & & & & 12 & & & & 1 & & & & & \\
\hline $\begin{array}{l}\text { Dendrophyra } \\
\text { arborescens }\end{array}$ & & & & & & & & & & 2 & 1 & & & & & & & & \\
\hline Eggerelloides sp. 1 & & & & & 1 & & & 1 & & & 3 & & & & & 1 & 4 & & 14 \\
\hline Evolutinella rotulata & & 1 & & & & & & & & & & & & & & & & & \\
\hline $\begin{array}{l}\text { Glaphyrammina } \mathrm{cf} \\
\text { americana }\end{array}$ & 1 & & & & & & & & & & & & 1 & 15 & 2 & & & & \\
\hline Hormosinella distans & & & 2 & & & & & & & & & & & & & & & & \\
\hline $\begin{array}{l}\text { Hormosinelloides sp. } \\
\text { aff. H. guttifer }\end{array}$ & 1 & 1 & 1 & & & & & & & & & & & 6 & & & & & \\
\hline Hyperammina spp. & 3 & & & & & 1 & & & & 2 & & & & & & & & & \\
\hline Karreriella sp. 1 & & & & 1 & & & & & & & & & & & & & & & \\
\hline $\begin{array}{l}\text { Lagenammina sp. } \\
\text { 'spicules' }\end{array}$ & & 1 & & & & & & & & & & & & & & & & & \\
\hline Lagenammina spp. & & & 1 & & & & & & & 1 & & & 1 & & & & & & \\
\hline $\begin{array}{l}\text { Large agglutinated } \\
\text { 'plate' }\end{array}$ & 2 & & & & & & & & & 3 & & 1 & 3 & & 2 & 2 & & & 1 \\
\hline Marsipella elongata & & & 1 & & & & & & & & & & & & & 1 & & & 1 \\
\hline Martinotiella sp. 3 & & 1 & & & 19 & 1 & 4 & 8 & 1 & & & & & & & & & & \\
\hline $\begin{array}{l}\text { Nodulina } \\
\text { dentaliniformis }\end{array}$ & 5 & & 9 & & 1 & & 1 & & & 4 & & & & & & & & & \\
\hline $\begin{array}{l}\text { Nothia sp. 'large } \\
\text { spicules' }\end{array}$ & & 1 & & & & & 1 & & & & & & & & 1 & & & & \\
\hline ?Nothia sp. 'diatoms' & & & & & & & & & & & & & & & 2 & & 2 & 1 & \\
\hline $\begin{array}{l}\text { Psammosiphonella } \\
\text { discrete }\end{array}$ & & & 4 & 6 & & & & 1 & & & & & & & & 1 & & & 4 \\
\hline Psammosphaera fusca & 2 & 1 & & & & & & & & 1 & 1 & & 1 & 3 & & & & & \\
\hline Recurvoides spp. & 1 & & 8 & 1 & & & & 1 & & 4 & & & 2 & & & 2 & 2 & 4 & 6 \\
\hline Reophanus oviculus & & & 11 & & & & & & & & & & & 7 & & & & & \\
\hline Reophax aff. brevis & & & 1 & & & & & & & & & & & & & & & & \\
\hline Reophax agglutinatus & 1 & & & & 1 & 1 & 1 & & 1 & & 1 & & & 1 & & & & & \\
\hline Reophax bilocularis & & & & & & & 1 & & & 13 & & & & 3 & & 2 & & & 1 \\
\hline Reophax duplex & & & & & & & & & & & & & 1 & & & & & & \\
\hline Reophax excentricus & & & 4 & & & & & & & 11 & & & 3 & & & & 5 & & 8 \\
\hline
\end{tabular}


Reophax sp. B 'tufty

spicules'

Reophax spiculifer

Reophax spp.

Rhabdammina

abyssorum

Rhabdammina

cylindrica

Rhabdammina sp.

Rhabdammina sp.

'smooth spicules'

Rhabdamminella

cylindrical

Rhizammina

algaeformis

Rhizammina sp.

'straight large'

Saccorhiza ramosa

Soft saccamminid

Subreophax splendidu

Thurammina albicans

Tolypammina vagans

Trochammina sp.

Veleroninoides scitulus

Forams per sample

Species per sample

Specimens stained with Rose Bengal (live fauna) are indicated, which constitute 9 stained specimens in sample 323-U1342, and 7 stained specimens in sample 323-U1345. 
Table 3. Semi-quantitative abundances of calcareous foraminifera in core-top samples from IODP Expedition 323 sites

\begin{tabular}{|c|c|c|c|c|c|c|c|c|c|c|c|c|c|c|c|c|c|}
\hline Species & U1339D & U1340A & U1341A & U1341B & U1341C & U1342C & U1342D & U1343A & U1343B & U1343C & U1343D & U1343E & U1344A & U1344B & U1344C & U1344D & U1345D \\
\hline Preservation & G & $\mathrm{G}$ & G & VG & VG & VG & VG & G & VG & G & G & G & G & VG & M & G & G \\
\hline Alabaminella weddellensis & & $\mathrm{P}$ & & & & & & & & & & & & & & & \\
\hline Bolivina sp. & $\mathrm{F}$ & & & & $\mathrm{F}$ & & & & & & & & & & & & A \\
\hline Brizalina cf. spathula & & & & $\mathrm{F}$ & & $\mathrm{F}$ & A & $\mathrm{P}$ & & & $\mathrm{P}$ & $\mathrm{P}$ & & & & & $\mathrm{F}$ \\
\hline Brizalina earlandi & & $\mathrm{R}$ & & $\mathrm{R}$ & & A & $\mathrm{F}$ & $\mathrm{R}$ & & $\mathrm{P}$ & $\mathrm{F}$ & $\mathrm{P}$ & & & & $\mathrm{R}$ & \\
\hline Brizalina pygmaea & & & & $P$ & $\mathrm{P}$ & A & A & $P$ & & & & & & & & & \\
\hline Bulimina aff. exilis & & $\mathrm{P}$ & & A & & A & $\mathrm{F}$ & $\mathrm{R}$ & $\mathrm{F}$ & $\mathrm{R}$ & A & $\mathrm{P}$ & & & & & $\mathrm{D}$ \\
\hline Bulimina sp. & & $P$ & & & $\mathrm{D}$ & & & $\mathrm{P}$ & & & & & & & & & \\
\hline Cancris cf. phillipinensis & & & & & & $\mathrm{F}$ & & & & & & & & & & & \\
\hline Cassidulina sp. & & & & & & & $\mathrm{D}$ & $\mathrm{F}$ & & & & & & & & & \\
\hline Cassidulinoides tenuis & & & & & & & & & $\mathrm{P}$ & & & & & & & & \\
\hline Elphidium cf. batialis & $\mathrm{F}$ & & & & & & & $\mathrm{P}$ & & & & $\mathrm{R}$ & & $\mathrm{R}$ & & & $\mathrm{R}$ \\
\hline Epistominella pulchella & & & & & $\mathrm{R}$ & & & & & & & & & & & & \\
\hline Globobulimina auriculata & & & & $\mathrm{P}$ & $\mathrm{F}$ & & & & $\mathrm{P}$ & & $P$ & & & $\mathrm{P}$ & & & \\
\hline Globobulimina pacifica & $\mathrm{R}$ & & $\mathrm{P}$ & $\mathrm{F}$ & & & $\mathrm{P}$ & $\mathrm{R}$ & $\mathrm{R}$ & $\mathrm{R}$ & & $\mathrm{F}$ & $\mathrm{P}$ & $\mathrm{R}$ & & & $\mathrm{R}$ \\
\hline Globocassidulina sp. & & $\mathrm{P}$ & $\mathrm{P}$ & & & & & & & $\mathrm{P}$ & & & & & & & \\
\hline Gyroidinoides soldanii & & & & & & & & & & & & & & $\mathrm{P}$ & & & \\
\hline Islandiella norcrossi & $\mathrm{R}$ & $P$ & & & & $\mathrm{~F}$ & & $\mathrm{P}$ & & $\mathrm{P}$ & & $\mathrm{P}$ & $\mathrm{R}$ & & & & $\mathrm{R}$ \\
\hline Nodosaria spp. & & & & & & & & & $\mathrm{P}$ & & & & & & & & \\
\hline Nonionella labradorica & $\mathrm{F}$ & & & & & & & $\mathrm{R}$ & $\mathrm{F}$ & $\mathrm{R}$ & $\mathrm{R}$ & A & & $\mathrm{F}$ & & & \\
\hline Nonionella turgida & & & & $\mathrm{R}$ & & & & & & & & & & $P$ & & & \\
\hline Nonionella turgida digitata & & & & & & & & $\mathrm{R}$ & A & $\mathrm{P}$ & A & $\mathrm{P}$ & & & $\mathrm{P}$ & & \\
\hline Procerolagena cf. gracillima & & & & & & & & & & $\mathrm{P}$ & $\mathrm{R}$ & & & & & & \\
\hline Pullenia bulloides & & & & & & & & & & & & $\mathrm{P}$ & & & & & \\
\hline Pygmaeseistron cf. hispida & & & & & & & & & & & & $\mathrm{P}$ & & & & & \\
\hline Pyrgo sp. & & & & & & & & & & & & & & $\mathrm{R}$ & & & \\
\hline Quinqueloculina sp. & & & & & & & & & & & & & & $\mathrm{R}$ & & & \\
\hline Stainforthia aff. fusiformis & & $\mathrm{P}$ & & & & & $\mathrm{R}$ & $\mathrm{P}$ & & & & & & & & & \\
\hline Triloculina cf. trihedra & & & & $\mathrm{P}$ & & & & & & & & & & & & & \\
\hline Uvigerina auberiana & & & $\mathrm{P}$ & & $\mathrm{R}$ & & & & & & & & & $\mathrm{F}$ & & & \\
\hline Uvigerina cf. peregrina & A & & $\mathrm{P}$ & & & & & $\mathrm{R}$ & $\mathrm{P}$ & $\mathrm{P}$ & & $\mathrm{P}$ & & & & & $\mathrm{F}$ \\
\hline Valvulineria sp. & & & & & & & $\mathrm{R}$ & & & $\mathrm{P}$ & & & & & & & \\
\hline
\end{tabular}

\footnotetext{
From Expedition 323 Scientists (2011). D, dominant; A, abundant; F, few; R, rare; P, present; VG, very good; G, good; M, medium.
} 


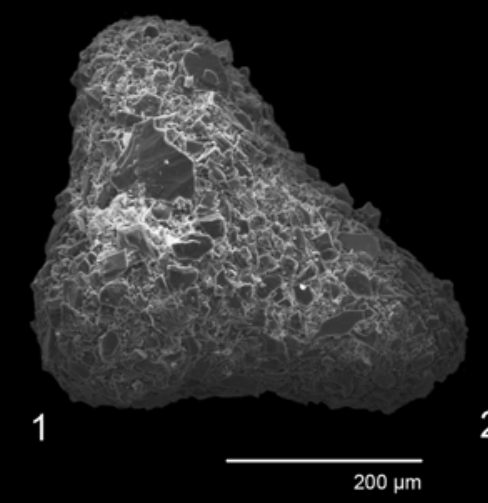

2

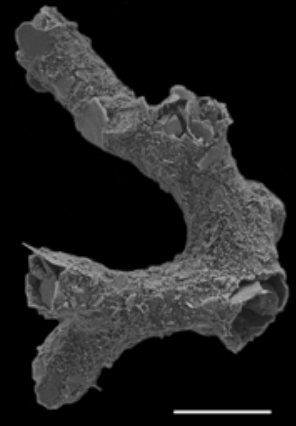

3

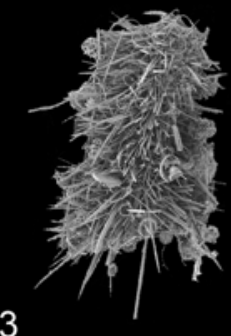

-

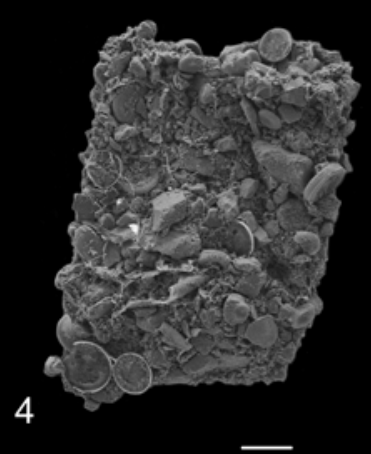

8
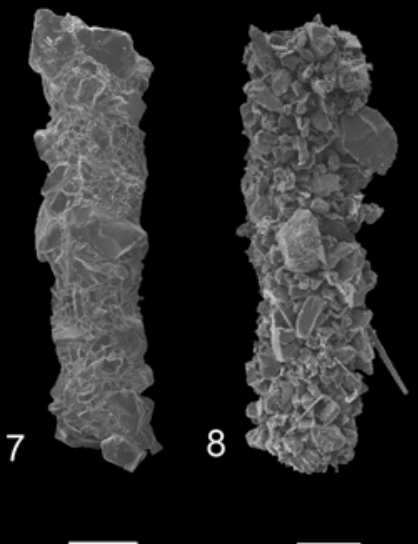

6

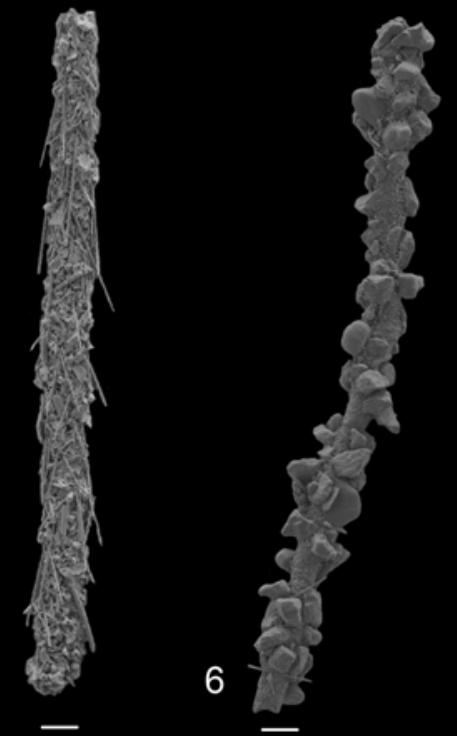

11

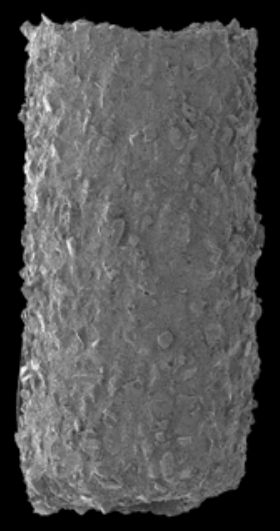

12

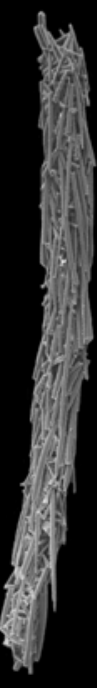

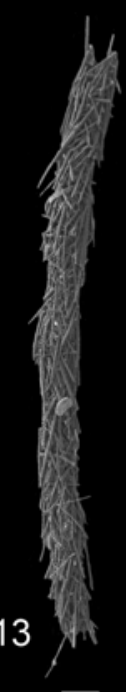

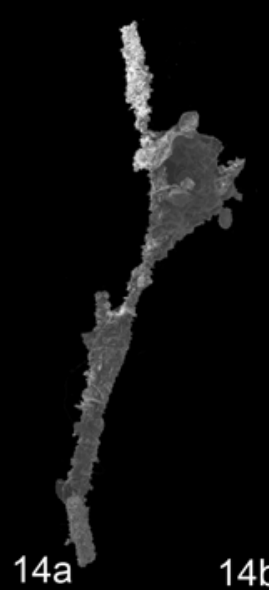

$14 b$

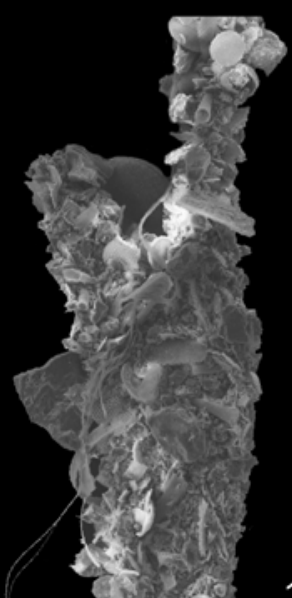

15

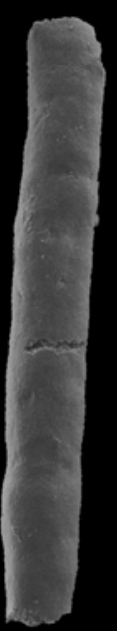

9

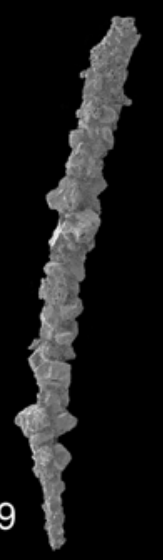

10

$$
\text { - }
$$
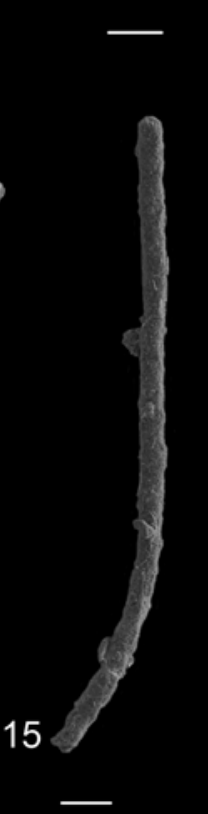

Fig. 6. (1) Astrorhiza granulosa (Brady, 1879), Hole U1342B. (2) Dendrophyra sp., Hole U1343A. (3) Nothia sp. 'large spicules', Hole U1341A. (4) ? Nothia sp. 'diatoms', Hole U1345B. (5) Marsipella elongata Norman, 1878, Hole U1342A. (6 - 8) Rhabdammina spp.: 6, Hole U1342A; 7 - 8, Hole U1344. (9) Bathysiphon sp. 'coarse', Hole U1341A. (10) Bathysiphon filiformis G.O. \& M. Sars, 1872, Hole U1345C. (11) Psammosiphonella discreta (Brady, 1881), Hole U1341A. (12 - 13) Rhabdamminella cylindrica (Brady, in Tizard \& Murray, 1882): 12, Hole U1340A; 13, Hole U1339A. (14a, b) Rhizammina algaeformis Brady, 1879, Hole U1344. (15) Rhizammina sp. 'straight large'. Hole U1342B. Scale bar $200 \mu \mathrm{m}$. 
foraminifera were studied by Matoba \& Fukusawa (1992) in the semi-enclosed Sea of Japan, and $26 \%$ of the reported taxa were not identified at species level.

\section{Ecological implications}

Benthic foraminifera are impacted by several ecological forcing factors, which include organic carbon type and flux, bottom water oxygenation, bottom water sediment heterogeneity and hydrodynamics, temperature and corrosiveness (Jorissen et al. 1995, 2007; Levin et al. 2001). Bering Sea deep-water (>800 m water depth) ecology is primarily affected by two of these ecological forcing factors: dissolved oxygen concentrations and organic carbon flux (Expedition 323 Scientists 2011), which is related to primary productivity (quantity, type and duration) and remineralization of particulate organic carbon as it is transported to depth (Arndt et al. 2013). Other factors that might affect benthic assemblages in the Bering Sea are the high sedimentation rates along the slope (Table 1). Oxygen levels in the deep Bering Sea are very low (c. $2.0-0.2 \mathrm{ml} \mathrm{l}^{-1}$ ), and primary productivity highly variable (Figs 2 and 3), which can be expected to impact upon assemblage composition (e.g. Jorissen et al. 1995, 2007; Kaminski et al. 1995; Sun et al. 2006). Indeed, oxygen concentrations in the bottom water have been hypothesized as significantly reduced compared with the open Pacific (Fig. 3) since at least the Pliocene, when laminations are pervasive in Bering Sea sediment cores and occasional calcareous faunas are dominated by deep infaunal taxa (Expedition 323 Scientists 2011).

The diverse calcareous and agglutinated foraminifera reported in the core-top material (Tables 2 and 3) are somewhat typical for low oxygen and high productivity environments, as described from the Santa Catalina Basin (Kaminski et al. 1995), Santa Barbara Basin (Moffitt et al. 2014), the Arabian Sea (Gooday et al. 2000; Schumacher et al. 2007) and OMZs elsewhere (see Sen Gupta \& Machain-Castillo 1993). Assemblages within the core of the OMZ are typically dominated by calcareous infaunal taxa that exhibit elongated tapered tests, which are predominantly Bulimina, Brizalina and Bolivina in the Bering Sea (Table 3). The relatively less-specialized agglutinated foraminifera usually occur in higher abundances above and below the core of the OMZ (Kaminski et al. 1995; Schumacher et al. 2007). Our samples are dominated by calcareous foraminifera, which is consistent with high productivity and low oxygen settings in the Okhotsk Sea (Bubenshchikova et al. 2008). The most commonly occurring cosmopolitan agglutinated species in our material (Fig. 4) are wide-ranging and described from diverse environments. Rhizammina algaeformis and Nodulina dentaliniformis are well-known cosmopolitan species ranging from neritic to abyssal depths. Nodulina dentaliniformis has been recorded from relatively shallow water in the Arctic (Lukina 2001) and Antarctic (Majewski 2005) where it may be tolerant of changes in salinity. Reophax excentricus and Reophax bilocularis are cosmopolitan open ocean species, and were recorded as part of assemblages within the OMZ of the Santa Catalina Basin (Kaminski et al. 1995). Reophax bilocularis was also recorded in high proportions along the slope beneath the Arabian Sea OMZ associated with high sedimentation rates (Hermelin \& Shimmield 1990) and occurs in relatively high abundances at Site U1343 along the slope, where sedimentation rates are higher (Table 1). Cyclammina compressa is a less well-known bathyal to abyssal species originally described from the Philippines and also recorded offshore North Carolina (Gooday et al. 2001), and has close morphological affinities with the cosmopolitan and wide-ranging $C$. cancellata (see Jones 1994).

Although we obtained no faunal density data (because of the limited availability of equipment onboard the JOIDES Resolution), with such strong ecological gradients between sites it is possible to speculate on the ecology of some of the more abundant key species (Fig. 4). We caution that our estimates of modern ecological parameters (i.e. dissolved bottom water oxygen and primary productivity, Figs 2 and 3; Table 1) at each site are only approximations, as there were no in situ water mass measurements made during Expedition 323. The line section of Figure 3 does, however, pass in close proximity to all sites apart from U1339 (see line in Fig. 1). It should also be considered that our benthic faunas probably represent several decades at least, and that the primary productivity proxy chlorophyll- $a$, with its own proxy uncertainties (see Sun et al. 2006), represents the years 1998-2003. In addition, primary productivity has only an indirect impact on benthic faunas, as much of the organic carbon is remineralized on its way to the seafloor (see Arndt et al. 2013). However, we consider that the largest changes in these parameters between sites will be semiquantitatively resolved by our estimates. Glaphyrammina cf. americana is restricted to Site U1344 (central slope), where the highest bottom water oxygen, highest sedimentation rate and deepest water depth is recorded (Table 1). The deep-water setting probably experiences lower organic carbon fluxes compared to the other slope sites (as organic carbon is remineralized in the water column) and so this species may be adapted to more oligotrophic environments with relatively elevated oxygen levels. At Site U1345 (northern slope), where there is the highest year-round chlorophyll$a$ concentration (and assumed organic carbon flux) and low bottom water oxygen (Figs 2 and 3), the endemic species Eggerelloides sp. 1 occurs in relative high abundance (Fig. 4; Table 2) and therefore this species may be adapted to high organic carbon flux in low oxygen settings. The morphologically similar species from the North Pacific, Eggerelloides advenum, has been associated with intense eutrophication in Osaka Bay (Tsujimoto et al. 2006). At Sites U1342 and U1340 (Bowers Ridge), the only other sites situated in the core of the OMZ (Fig. 1), the endemic species Martinottiella sp. 3 is observed (Fig. 4; Table 2). Due to its distribution, we speculate that this species may be adapted to low oxygen environments (e.g. below $c .1 \mathrm{ml} \mathrm{l}^{-1}$; Table 1), but not high organic carbon flux (as it does not occur along the northern slope but in the more oligotrophic south-central Bering Sea). Kaminski et al. (2013) were the first to observe the highly perforate tests of Karreriella and Martinottiella from the Bering Sea (see Fig. 10:110:5) and suggested this feature may have been an adaptation to severely hypoxic conditions, which is supported by the species modern distribution recorded here. Martinottiella sp. 3 is larger and more robust than the otherwise morphologically similar species Martinottiella sp. 1, recorded from the Pliocene of Bowers Ridge (Kaminski et al. 2013), which may have been its evolutionary ancestor. The modern-day distribution of the morphologically similar (although possibly lacking perforations) Martinottiella sp. (cf. M. communis) is world-wide, including within the $\mathrm{OMZ}$ of the Santa Catalina California Borderland basin (Kaminski et al. 1995), highly productive areas of the South China Sea (Jian et al. 1999), the OMZ of the equatorial East Pacific (Culver \& Buzas 1987) and East New Zealand, South Pacific (Hayward et al. 2001). It is sometimes associated with high organic carbon flux and low oxygen settings, but its modern-day ecology is yet to be fully resolved. Martinottiella spp. is dissolution resistant and survives taphonomic loss, so this taxon can be used as a palaeoenvironmental indicator. Echols (1973), Expedition 323 Scientists (2011) and Kaminski et al. (2013) recorded Martinottiella sp. (cf. M. communis) from several locations in the Bering Sea (including Bowers Ridge) from the Pliocene to Recent. Due to the new distributional data reported here, we suggest that the significance of the Pliocene occurrences of Martinottiella may be an indication of low oxygen conditions at times since at least the Pliocene. Our study highlights, however, the importance of obtaining more bottom water and surface sample material from the Aleutian Basin for further study. 
We cannot be sure of Eggerelloides sp. 1 and Martinottiella sp. 3 living depth preferences within the sediment. However, many authors have attempted to ascertain palaeoecology from ancient sediments by placing agglutinated foraminifera into groups on the basis of their morphology; these 'morphogroups' are thought to be indicative of their ecology (e.g. Nagy 1992; van den Akker et al. 2000; Kaminski et al. 2005; Kender et al. 2008a, b; Nagy et al. 2009; Nikitenko et al. 2013). These are based on studies of modern foraminifera and bottom water properties, such as living depth, productivity and ecological disturbance (Jones \& Charnock 1985; Kaminski et al. 1995). Both Eggerelloides and Marttinotiella are elongated and tapered in shape and would be assigned to the 'morphogroup 4b' of Kaminski \& Gradstein (2005), a group regarded as infaunal and tolerant of low oxygen conditions. This approach to reconstructing palaeoenvironments using morphogroups should be taken with caution and may be an oversimplification (e.g. Sen Gupta \& Machain-Castillo 1993; Jorissen et al. 2007), particularly as Eggerelloides and Martinottiella do not co-occur in the same samples (Table 2). However, the distribution of this group within the Bering Sea OMZ sites (U1340, U1342 and U1345; see distribution in Fig. 1) supports the interpretation of an infaunal living habit.

\section{Conclusions}

We document the occurrence of 50 modern agglutinated foraminiferal taxa at IODP Expedition 323 sites in the Bering Sea, and provide the first descriptions and illustrations. The 19 core-top samples at seven sites, U1339, U1340, U1341, U1342, U1343, U1344 and U1345, contain abundant agglutinated foraminifera in varying proportions, and calcareous benthic foraminifera previously reported (Expedition 323 Scientists 2011), many of which are typical for reduced oxygen and high productivity environments. The agglutinated foraminifera consist of several abundant and ecologically wide-ranging cosmopolitan taxa, and also a number of taxa (e.g. Glaphyrammina, Martinottiella, Eggerelloides, Bathysiphon, Hormosinelloides and Karreriella) that differ in morphology from their counterparts and are here left in open nomenclature. The agglutinated foraminiferal fauna of the deep Bering Sea is thus partially endemic, suggesting that geographical restriction, combined with high productivity and low oxygen environmental conditions, may have persisted within the Bering Sea for a geologically extended period of time, considering the low evolutionary rate of the group. Three of the more abundant endemic species may be ecologically restricted. Glaphyrammina cf. americana occurs largely at the slope Site U1344, which is the deepest (with likely low organic carbon flux), highest bottom water oxygen and highest sedimentation rate site sampled. Eggerelloides sp. 1 occurs in high abundance at the northern slope Site U1345, which experiences the highest seasonal productivity (and possibly organic carbon flux) of the seven sites. Martinottiella sp. 3 is restricted to the $\mathrm{OMZ}$ of Bowers Ridge, where there is currently relatively low annual productivity, suggesting this species may be a good indicator for reduced oxygen conditions but not elevated organic carbon flux. The occurrence of Martinottiella throughout the Bering Sea sporadically over the past c. 4 Ma (Echols 1973; Expedition 323 Scientists 2011; Kaminski et al. 2013) therefore adds evidence to the hypothesis that the Bering Sea has had a pronounced $\mathrm{OMZ}$ since at least the Pliocene. However, due to the relatively low number of samples, our study highlights the importance of collecting more data from the currently undersampled deep Aleutian Basin. In addition, two species of agglutinated foraminifera (Karreriella sp. 1 and Martinottiella sp. 3) were found to contain micro-pores that are open at the test surface, a morphological feature that is possibly indicative of hypoxia (Kaminski et al. 2013).

\section{Systematic palaeontology}

In this section species are arranged in taxonomic order according to the classification of Kaminski (2014). Descriptions and comments are provided and important references for understanding each species morphology and distribution are cited. For taxonomic determinations the monographs of Cushman (1910, 1921, 1944), Cushman \& McCulloch (1939), Pfleger (1952), Vilks (1969), Saidova (1975), Wollenberg (1992, 1995), Jones (1994), Kaminski \& Gradstein (2005) and Vázquez Riveiros \& Patterson (2007) were mainly used, and direct comparisons were made with specimens preserved in the HMS Challenger Collections at the Natural History Museum (London). The specimen microslides have been deposited in the collections of the European Micropalaeontological Reference Centre at Micropress Europe, Kraków Poland.

Subclass Monothalamana Pawlowski, Holzmann \& Tyszka, 2013

Genus Astrorhiza Sandahl, 1858

Astrorhiza granulosa (Brady, 1879)

(Fig. 6:1)

1879 Marsipella granulosa Brady: 38, pl. 3, figs 8 - 9 .

1881 Astrorhiza granulosa (Brady); Brady: 48.

1884 Astrorhiza granulosa (Brady); Brady, 234, pl. 20, figs 14-23. 2000 Astrorhiza granulosa (Brady); Gooday \& Smart: 107, pl. 4, figs $1-7$.

Remarks. A single specimen was found in Hole U1342A. It is triangular in outline, with a coarsely agglutinated wall. It corresponds well with specimens illustrated by Brady (1884, pl. 20). Gooday \& Smart (2000) showed that the species has a two-layered wall and agglutinates juvenile planktonic foraminiferal tests to construct its outer layer. Our specimen from Hole U1342B only uses mineral grains.

Genus Marsipella Norman, 1878

Marsipella elongata Norman, 1878

(Fig. 6:5)

1878 Marsipella elongata Norman: 281, pl. 16, fig. 7. 1884 Marsipella elongata Norman; Brady: 264, pl. 24, figs $10-19$ 2008 Marsipella elongata Norman; Kaminski et al.: 64, pl. 2, figs $1-4$.

Description. Test up to $3 \mathrm{~mm}$ in length, elongated, tubular, cylindrical, or tapering at both ends, may be slightly twisted or sinusoidal. Wall thin, of agglutinated quartz grains and sponge spicules, firmly cemented. Spicules are concentrated near the tapering ends of the tube. Apertures at the open ends of the tube.

Remarks. The type specimen in the Norman Collection is from Porcupine Station 87 in the North Atlantic (59 $35^{\prime}$ N, $9^{\circ} 11^{\prime}$ W; 767 fathoms) and is preserved in the NHM, London, in slide 1915.4.1.852. The specimens from Hole U1345C conform well with the type specimen.

\section{Genus Rhabdammina Sars in Carpenter, 1869}

\section{Rhabdammina spp.}

(Fig. 6:6-6:8)

Remarks. We used this name to describe fragments of straight tubes, not precisely determined. A distinctive specimen recovered in 
Hole U1343A agglutinates grains of very unequal size.

$$
\text { Rhabdammina 'smooth spicules' }
$$

Remarks. A single specimen was found in Hole U1340A. This species has a very thick wall with sponge spicules embedded in a matrix of finer agglutinated particles. The spicules are aligned at right angles to the long axis of the test.

\section{Bathysiphon Sars, 1872 \\ Bathysiphon sp. 'coarse'}

(Fig. 6:9)

Remarks. A large specimen was recovered at Site U1341. The test is over $3 \mathrm{~mm}$ in length, arched and the early part of the test is tapered. The wall is coarsely agglutinated and constructed of grains of uneven dimensions. It most closely resembles Bathysiphon rufus de Folin, but the species in the NE Atlantic can reach a much larger size, up to $14 \mathrm{~mm}$ in length (Gooday 1988a). Gooday (1988b) designated a lectotype of $B$. rufus from the de Folin Collection, but the type locality is unknown.

\section{Bathysiphon filiformis G.O. \& M. Sars in Sars, 1872}

(Fig. 6:10)

1872 Bathysiphon filiformis G.O. \& M. Sars in Sars: 251. 1988b Bathysiphon filiformis G.O. \& M. Sars in Sars; Gooday: 97, figs $1-3$ (fig. 1a is the neotype).

Remarks. Test consists of a straight unbranched elongated tube, broken at both ends. Wall very finely agglutinated, thick, with a smooth finish. Gooday (1988b) credited the authorship of the species to both authors - G.O. \& M. Sars - and designated a neotype from the Brady Collection (ex Norman collection, Hardanger Fjord, Norway). The specimen is preserved at the NHM, London, in slide BNHM 1887.8.31.1. The specimens from Hole U1341A and U1345C are fragmentary, but conform well to the types.

\section{Genus Nothia Pflaumann, 1964}

Nothia sp. 'large spicules'

(Fig. 6:3)

Remarks. A thin-walled tube constructed of fine mineral grains with agglutinated sponge spicules attached to the surface of its test. The sponge spicules project at a $45^{\circ}$ angle away from the test. Only broken fragments were found.

$$
\begin{gathered}
\text { ?Nothia sp. 'diatoms' } \\
\text { (Fig. 6:4) }
\end{gathered}
$$

Remarks. We used this designation for fragments of a flattened thin-walled tube that contains a high proportion of diatoms incorporated into the wall. Specimens from Hole U1345B use a mixture of mineral grains and centric diatoms, while the specimens from Hole U1344D use mostly diatoms to construct their test. Fossil species of Nothia (e.g. Nothia excelsa Grzybowski) are commonly flattened, implying that their wall was flexible.

Genus Psammosiphonella Avnemelich, 1952

Psammosiphonella discreta (Brady, 1881)

(Fig. 6:11)
1884 Rhabdammina discreta Brady; Brady: 268, pl. 22, figs 8 - 10 . 1952 Psammosiphonella discreta (Brady); Avnemelich: 65.

2005 Psammosiphonella discreta (Brady); Kaminski \& Gradstein: 117 , pls $5-6$, figs $1-8$.

Description. Test tubular, round in cross-section, straight, of even diameter or with slight constrictions. The inner surface of the tube is even, not constricted. Wall thick, composed of mineral grains, mostly quartz with some dark mafic grains, with organic cement. Apertures at the open ends of the (broken) tube.

Remarks. The type specimens of $P$. discreta are from Porcupine station no. 4, 808 fathoms water depth in the North Atlantic (BMNH ZF 4863 -4865). A lectotype from this sample, corresponding to the specimen illustrated by Brady (1884, pl. 22, fig. 8), was designated by Kaminski \& Gradstein (2005). In the area of the Philippines, Cushman (1921) listed it from 221 to 985 fathoms depth. These specimens are much larger (up to $18 \mathrm{~mm}$ length) and are comprised entirely of quartz grains. Our specimens are broken into small fragments and agglutinate some dark grains, giving the test a 'salt and pepper' appearance.

Genus Rhabdamminella de Folin, 1887

Rhabdamminella cylindrica (Brady, in Tizard \& Murray, 1882) (Fig. 6:12, 6:13)

1882 Marsipella cylindrica Brady, in Tizard \& Murray: 714. 1884 Marsipella cylindrica Brady, in Tizard \& Murray; Brady: 265, pl. 24, figs $20-22$.

1987 Rhabdamminella cylindrica (Brady, in Tizard \& Murray); Loeblich \& Tappan: 23, pl. 14, figs 2, 3.

2008 Rhabdamminella cylindrica (Brady, in Tizard \& Murray); Kaminski et al.: 65 , pl. 3, figs $3-5$ (fig. 3 is the lectotype).

Description. Test an elongated slender tube of constant diameter, may be slightly arcuate. Wall constructed of firmly cemented acicular sponge spicules, aligned more or less parallel to the long axis of the test in more or less irregular overlapping tiers; aperture at the open ends of the tube.

Remarks. Rhabdamminella differs from Marsipella in being fully composed of siliceous sponge spicules along the whole length of the test. Twelve specimens of 'Marsipella' cylindrica, including the specimens figured by Brady (1884), are preserved in the Brady Collection in the NHM, London in Slide ZF1811. A lectotype, corresponding to the specimen figured by Brady (1884, pl. 24, fig. 21), was selected and illustrated by Kaminski et al. (2008). Specimens from Holes U1339A and U1340A have sponge spicules that are not so perfectly aligned as in the type specimens in the Brady Collection.

Genus Dendrophyra Wright, 1861

Dendrophyra $\mathrm{sp.}$

(Fig. 6:2)

Remarks. Small thin-walled fragments, displaying dichotomous or trichotomous branching.

Genus Rhizammina Brady, 1879

Rhizammina algaeformis Brady, 1879

(Fig. 6:14)

1879 Rhizammina algaeformis Brady: 38, pl. 4, figs 16, 17. 
1884 Rhizammina algaeformis Brady; Brady: 274, pl. 28, figs 1 - 11 1990 Rhizammina algaeformis Brady; Schröder-Adams et al.: 35, pl. 1 , figs $6-7$.

Description. Test small, round in cross-section, occasionally branching dichotomously. Test wall is thin and comprised mostly of fine sand grains with occasional short fragments of sponge spicules or diatom frustules loosely attached to the surface of the test.

Remarks. Unlike the type specimens housed at the NHM, London, the specimens from the Bering Sea do not attach any planktonic foraminifera to the exterior of their test. Instead, the species attaches occasional sponge spicules or centric diatoms to its test surface. Our specimens more closely resemble those figured by Schröder-Adams et al. (1990) from the Axel Heiberg Shelf, Arctic Ocean.

\section{Rhizammina sp. 'straight large'}

(Fig. 6:15)

Description. Test small, round in cross-section, with the test wall comprised largely of biosiliceous fragments.

Genus Lagenammina Rhumbler, 1911

Lagenammina sp. 'spicules'

(Fig. 7:1)

Remarks. Test flask-shaped, tapering toward the aperture. Wall consists largely of biogenic siliceous particles, with long sponge spicules extending radially away from the test. A single specimen was found in Hole U1340A.

\section{Lagenammina sp.}

Remarks. A specimen from Hole U1341A is comprised mostly of biogenic siliceous particles, including centric diatoms. The species of Lagenammina made of quartz grains (e.g. L. atlantica and $L$. arenulata), which are so common in the Arctic, have not been found in our material from the Bering Sea.

\section{Genus Psammosphaera Schultze, 1875}

\section{Psammosphaera fusca Schultze, 1875}

(Fig. 7:2)

1875 Psammosphaera fusca Schulze: 113, pl. 2, fig. 8a-f.

Description. Test free or attached to a single large sand grain, varying in size, consisting of a single spherical chamber. Wall agglutinated, of a single layer of coarse sand grains, cemented together in a matrix of finer agglutinated particles, without any inner organic layer. Small pores between the loosely agglutinated sand grains serve as apertures.

Remarks. The species $P$. fusca uses a combination of larger and smaller agglutinated particles, sometimes selecting a single larger grain that may serve as an attachment surface. The large agglutinated grains may be angular or sub-rounded. Space between grains is filled in by a matrix of much finer agglutinated particles. The size of the recovered specimens is variable. Smaller specimens build their test out of only a few $(<10)$ grains. Already in 1948, Cushman (1948, p. 9) noted 'All the Arctic specimens I have seen are small with rather large, angular quartz grains, and quite different from some of the specimens that are figured and referred to this species'. We observed this species at Sites U1339, U1340, U1343, and U1344.

Large agglutinated 'plate'
Remarks. In Hole U1345C, platy fragments of a larger agglutinated foraminifera were found. These fragments consist of equidimensional sand grains that include some mafic grains, cemented in a groundmass of much finer quartz grains. The grains are orientated in such a manner that the flat surfaces of the grains face the interior of the chamber. The agglutinated plates show little or no curvature, which means the whole specimen must have been quite large. These specimens are similar to the taxon that was named 'Astrorhizinella' by Saidova (1970). Loeblich \& Tappan (1987) included this taxon in their list of genera with uncertain status, with the remark that it could be a foraminifera, xenophyophorean or inorganic.

Subclass Turbothalamana Pawlowski, Holzmann \& Tyszka, 2013

Genus Saccorhiza Eimer \& Fickert, 1899

Saccorhiza ramosa (Brady, 1879)

(Fig. 7:3)

1879 Hyperammina ramosa Brady: 33, pl. 3, figs 14, 15.

2011 Saccorhiza ramosa (Brady); Kaminski \& Cetean: 62, pl. 1, figs $11-12$ (lectotype).

Description. Test with smaller diameter than other tubular species. Proloculus or branching not observed. Wall predominantly of agglutinated quartz grains, with yellowish-brown organic cement, with a large component of outwardly projecting sponge spicules that give the surface a hirsute appearance.

Remarks. The specimens from Hole U1341A select sponge spicules that project out from the agglutinated tube at angles from 60 to $90^{\circ}$

Genus Archimerismus Loeblich \& Tappan, 1984

$$
\text { Archimerismus subnodosus (Brady, 1884) }
$$
(not figured)

1884 Hyperammina subnodosa Brady: 259, pl. 23, figs 11-14. 1984 Archimerismus subnodosus (Brady); Loeblich \& Tappan: 1161.

2011 Archimerismus subnodosus (Brady); Kaminski \& Cetean: 63, pl. 1, figs $13-15$ (lectotype).

Description. Test free, very large ( $>2 \mathrm{~mm})$, tubular or cylindrical, open only at one end, proloculus with approximately the same diameter as the tubular chamber. The fragments of the tubular chamber are several $\mathrm{mm}$ in length and may display constrictions or taper slightly toward the aperture. Wall is several grains thick, of fine sand with occasional larger sand grains, occasional diatom frustules and dark mafic grains, with little cement, grey in colour. The test appears to be comprised of two layers: the interior layer is much thinner, with smaller sand grains lining the central cavity, which has a yellowish-brown inner organic lining. Aperture terminal, constricted, round in outline, may be partially obstructed by agglutinated particles.

Remarks. Three slides of type specimens of Hyperammina subnodosa are preserved in the Carpenter Collection in the NHM, London, all from Valorous Station 2, 100 fathoms. The lectotype, designated by Kaminski \& Cetean (2011), is the specimen illustrated by Brady (1884) in plate 23, figure 11, and is preserved in slide BMNH 1886.4.16.94. These specimens are quite large $(>1 \mathrm{~mm})$ for an agglutinated foraminifera. The diameter of the tubular chamber is variable in our specimens, giving the impression of pseudochambers. These pseudochambers sometimes taper toward the aperture and may be several $\mathrm{mm}$ in length. However, 

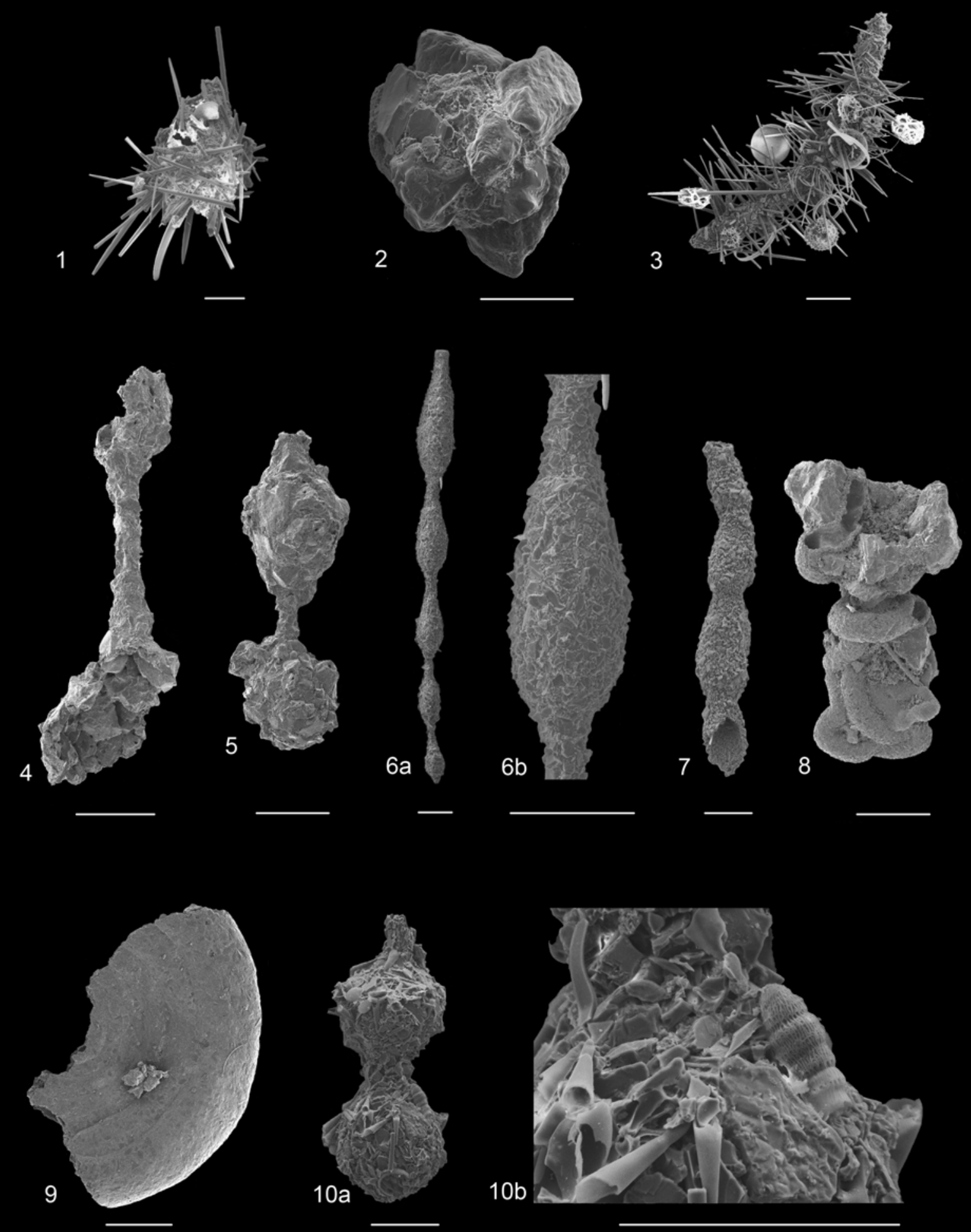

Fig. 7. (1) Lagenammina sp. 'spicules', Hole 1340A. (2) Psammosphaera fusca Schultze, 1875, Hole U1343E. (3) Saccorhiza ramosa (Brady, 1879), Hole U1341A. (4, 5) Hormosinella distans (Brady, 1881), Hole U1341A. (6a, b) Reophanus oviculus (Brady, 1879), Hole U1344. (7) Subreophax splendidus (Grzybowski, 1898), Hole U1341A. (8) Tolypammina vagans (Brady, 1879), Hole U1341A. (9) Ammodiscus sp., Hole U1341A. (10a, b) Hormosinelloides sp. aff. H. guttifer (Brady, 1884), Hole U1344. Scale bar $200 \mu \mathrm{m}$. 
the wall of the tubular chamber is continuous from one pseudochamber to the next; therefore, these are not true chambers. The interior layer contains smaller agglutinated grains than the outer layer, giving the interior a smooth appearance. This is the type species of the genus Archimerismus Loeblich \& Tappan, 1984, which differs from Hyperammina in the partial subdivision of the test to form pseudochambers. The species is found at Sites U1344 and U1345. Gooday et al. (2005) noted mass occurrences of the species at deeper stations in the outer reaches of the West Spitsbergen fjords.

Genus Hormosinella Stschedrina, 1969

Hormosinella distans (Brady, 1881)

(Fig. 7:4, 7:5)

1881 Reophax distans Brady: 50.

1884 Reophax distans Brady; Brady: pl. 31, figs 18-22.

2005 Hormosinella distans (Brady); Kaminski \& Gradstein: 246, pl. 45 , figs $1-11$.

2011 Hormosinella distans (Brady); Kaminski \& Cetean: 63, pl. 1, figs $16-17$ (lectotype).

Description. Proloculus round, followed by ovoid pseudochambers connected by thin stolons. Wall thin. Chambers taper toward the aperture.

Remarks. The subspecies of $H$. distans were discussed by Kaminski \& Gradstein (2005). The type specimens are from Challenger Station 300, (33 $\left.42^{\prime} \mathrm{S}, 78^{\circ} 18^{\prime} \mathrm{W}\right)$, north of Juan Fernández Island, South Pacific, 1375 fathoms. A lectotype was designated by Kaminski \& Gradstein (2005) and is preserved in the Brady Collection in Slide BMNH ZF 2271. Cushman (1910) recorded the species from two Albatross stations in the North Pacific and from the Bering Sea at 1771 fathoms.

Fragmentary coarsely agglutinated specimens were recovered at Site U1341, while specimens with as many as five chambers were found at Site U1344.

Genus Reophanus Saidova, 1970
Reophanus oviculus (Brady, 1879)
(Fig. 7:6a-b)

1879 Hormosina ovicula Brady: 61, pl. 4, fig. 6.

1884 Hormosina ovicula Brady; Brady: 327, pl. 39, figs 7-9.

1987 Reophanus oviculus (Brady); Loeblich \& Tappan: 61, pl. 46, fig. 10 .

2011 Reophanus oviculus (Brady); Kaminski \& Cetean: 63, pl. 2, figs $1-3$.

Description. Test large, exceeding $4 \mathrm{~mm}$ in length, uniserial, rectilinear, unilocular in appearance because the elongated ovate chambers are separated by their respective necks, each new chamber attaching to the upper margin of the previous apertural lip, so that the test is fragile and tends to break into individual chambers. Wall finely agglutinated with several layers of very fine quartz grains, with yellowish-brownish cement which is more prominent on the necks of the chambers, without an inner organic lining. Aperture rounded, terminal on a distinct neck, with somewhat flared lip.

Remarks. The type specimens of Hormosina ovicula are preserved in the Brady Collection in the NHM, London. The lectotype is the specimen illustrated by Brady (1884) in plate 39, figure 7 (Kaminski \& Cetean 2011). This specimen was designated the 'holotype' by
Loeblich \& Tappan (1987) and is preserved in slide BMNH ZF1588. The specimen is from Challenger Station 241, North Pacific at 2300 fathoms. It is the type species of the genus Reophanus Saidova, 1970.

This species is common in Hole U1341A and specimens consist of up to five chambers. The chambers (especially the proloculus) in our specimens are slightly more elongated than Brady's specimens from the North Pacific, but otherwise they conform very well to the original description of the species.

Genus Subreophax Saidova, 1975

Subreophax splendidus (Grzybowski, 1898)

(Fig. 7:7)

1898 Reophax splendida Grzybowski: 278, pl. 10, fig. 16. 1993 Subreophax splendidus (Grzybowski); Kaminski \& Geroch: 251, pl. 3, figs 11a-12b.

Description. Test comprised of a meandering series of uniserial pseudochambers. Pseudochambers are oval, elongated in the direction of growth and are connected by wide stolons. Wall thin, medium to coarse. Aperture wide, terminal.

Remarks. This species was originally described from the Palaeogene of the Polish Carpathians (Grzybowski 1898). The lectotype was designated by Kaminski \& Geroch (1993). It differs from Subreophax aduncus (Brady) in possessing a more coarsely agglutinated wall and chambers that are elongated in the direction of growth. A single specimen was found in Hole U1341A.

Genus Ammodiscus Reuss, 1862

Ammodiscus sp.

(Fig. 7:9)

Remarks. A large coarsely agglutinated fragment of a specimen consisting of $>6$ planispiral whorls was found in Hole U1341A.

Genus Tolypammina Rhumbler, 1895

Tolypammina vagans (Brady, 1879)

(Fig. 7:8)

1879 Hyperammina vagans Brady: 33, pl. 5, fig. 3.

1884 Hyperammina vagans Brady; Brady: 260, pl. 34, figs $1-5$. 1921 Tolypammina vagans (Brady); Cushman: 55, pl. 4, figs 2, 3; pl. 7, figs 1,2 .

Description. Test attached, tubular, of constant diameter, streptospirally coiled, finely agglutinated with a thin wall.

Remarks. Brady (1879) originally reported this species from the South Atlantic and from the North Pacific. Brady (1884) illustrated specimens that grew free or attached to shell fragments. Cushman (1921) reported that the species often attaches itself to other agglutinated foraminifera. Schröder (1986) reported that the species grows attached at bathyal depths in the North Atlantic, but is freeliving at abyssal depths.

A large specimen was recovered in Hole U1341A. Our specimen was probably free-living and most closely resembles the specimens illustrated by Cushman (1921, pl. 4) from the Philippine Seas.

Subclass Globothalamana Pawlowski, Holzmann \& Tyszka, 2013

Genus Hormosinelloides Zheng, in Zheng \& Fu, 2001 

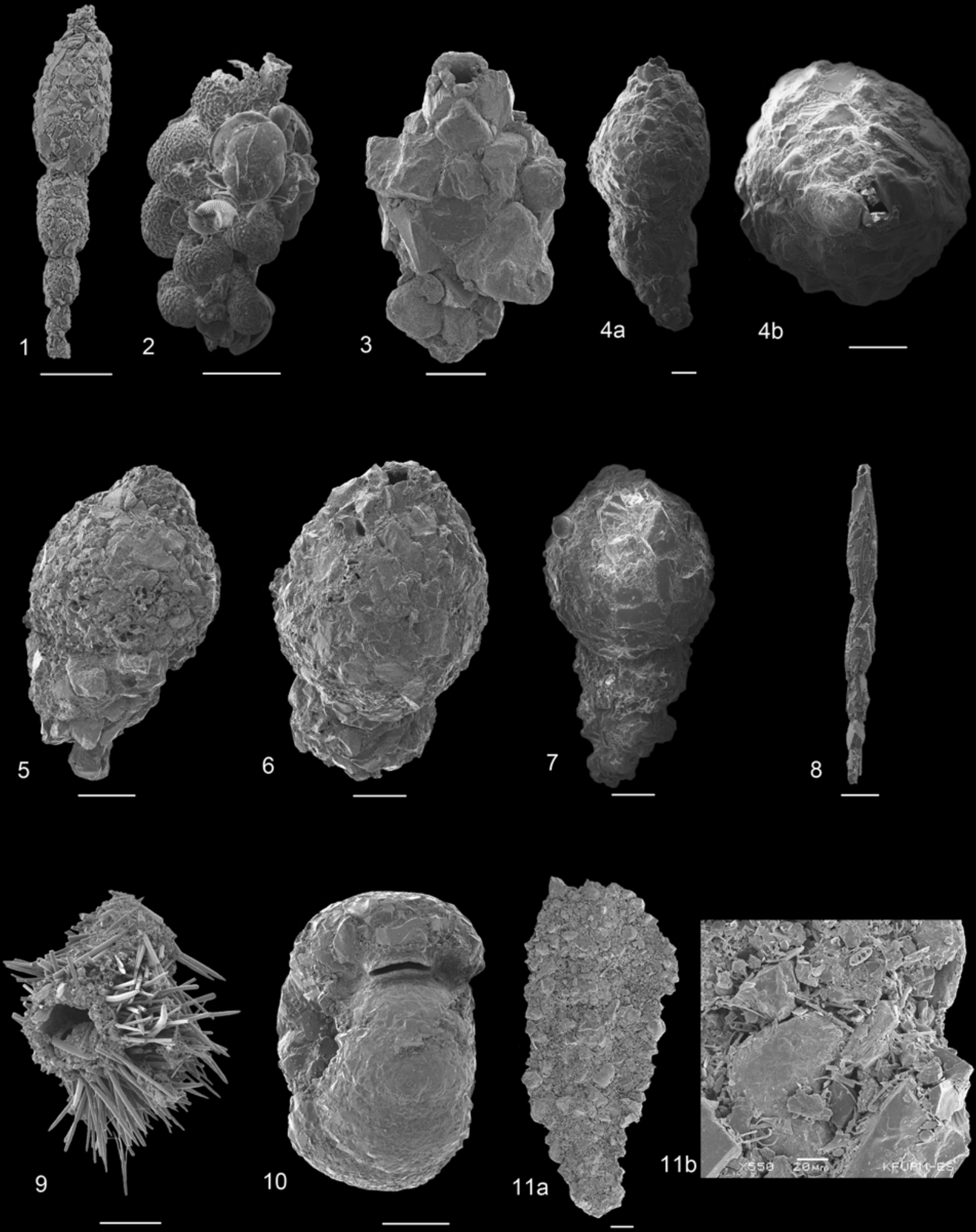

Fig. 8. (1) Nodulina dentaliniformis (Brady, 1881), Hole U1341A. (2) Reophax agglutinatus Cushman, 1913, Hole U1342D. (3) Reophax bilocularis Flint, 1899, Hole U1342B. (4) Reophax bradyi Brönnimann \& Whittaker, 1980, Hole U1343A. (5, 6) Reophax excentricus Cushman, 1910, Hole U1341A. (7) Reophax pilulifer Brady, 1884, Hole U1342A. (8) Reophax spiculifer Brady, 1879, Hole U1344D. (9) Reophax sp. 2 ‘tufty spicules’, Hole U1341A. (10) Veleroninoides scitulus (Brady, 1881), Hole U1343A. (11) Glaphyrammina cf. americana (Cushman, 1910), Hole U1344B. Scale bar $200 \mu \mathrm{m}$ unless labelled otherwise.

Hormosinelloides sp. aff. H. guttifer (Brady, 1884) (Fig. 7:10a-b)
1910 Reophax guttifer (Brady); Cushman: 88, fig. 123. 1969 Reophax guttifer (Brady); Vilks: 44, pl. 1, fig. 10. 
Description. Test free, small, consisting of two or three pyriform chambers. Aperture terminal, with a distinct neck.

Remarks. The specimens from Site U1344 are consistently made up of only few chambers and the wall is made of mineral grains as well as fragments of biosiliceous particles, such as sponge spicules and radiolarians (Fig. 7:10b). The type specimens of $H$. guttifer from Challenger Station 323 (South Atlantic, east of Buenos Aires at 1900 fathoms) are larger and consist of 8 or more chambers (Kaminski \& Cetean 2011, pl. 2, figs $10-12$ ). The chambers of the type specimens in the Brady Collection are slightly more pyriform than in our specimens, but they share the habit of incorporating small biogenic particles, such as radiolarians and sponge spicules, into their wall. Our specimens more closely resemble the Arctic variety of this species, which is smaller and has fewer chambers. The specimen illustrated by Vilks (1969) from Hecla Bay, Arctic Canada, is only a two-chambered individual.

Genus Nodulina Rhumbler, 1895

Nodulina dentaliniformis (Brady, 1881)

(Fig. 8:1)

1881 Reophax dentaliniformis Brady: 49.

1884 Reophax dentaliniformis Brady; Brady: 293, pl. 30, figs 21 - 22. 1980 Hormosina dentaliniformis (Brady); Brönnimann \& Whittaker: 265, figs $8-11$.

2011 Nodulina dentaliniformis (Brady); Kaminski \& Cetean: 65, pl. 2 , figs $19-22$.

Description. Test uniserial and rectilinear, similar to Reophax but with a straighter axis, more symmetrical, regular, with gradually enlarging chambers and nearly horizontal sutures. Wall coarsely agglutinated of a single layer of quartz grains. Aperture rounded, at the end of a short tubular neck.

Remarks. Brönnimann \& Whittaker (1980) selected a lectotype for the type species from the Brady Collection. The type locality is Challenger Station 300, north of Juan Fernández (1375 fathoms). This six-chambered specimen (labelled Hormosina dentalinifor$m i s$ ) is housed in slide BMNH 3990. Anderson (1963) listed the species in a single sample from the inner Bering Sea shelf. Our specimens from Hole U1341A possess up to five chambers and closely resemble those in the Brady Collection.

Genus Reophax de Montfort, 1808

Reophax agglutinatus Cushman, 1913

(Fig. 8:2)

1913 Reophax agglutinatus Cushman: 637, pl. 79, fig. 6.

1921 Reophax agglutinatus Cushman; Cushman: 73, pl. 14, figs 2a, b. 1939 Reophax agglutinatus Cushman; Cushman \& McCulloch: 59, pl. 3 , figs $1-3$.

Description. Test free, uniserial, comprised of two chambers, with the second one much larger than the first. Wall very coarsely agglutinated, comprised of quartz grains with an admixture of small planktonic and benthic foraminiferal tests and siliceous sponge spicules that extend outward from the test. Aperture at the end of a tapering neck.

Remarks. Differs from Reophax bilocularis in possessing small planktonic foraminifera incorporated into its wall and its more robust neck. Anderson (1963) listed the species in a single sample from the outer Bering Sea shelf. The large specimen from Hole U1342D is the typical form.

\section{Reophax bilocularis Flint, 1899}

(Fig. 8:3)

1899 Reophax bilocularis Flint: 273, p. 17, fig. 2.

1920 Reophax bilocularis Flint; Cushman: 10, pl. 3, figs 3, 4.

Description. Test free, uniserial, comprised of two chambers, with the second one much larger than the first. Wall very coarsely agglutinated, comprised of angular and rounded quartz grains with an admixture of some dark minerals, cemented with a matrix of much finer agglutinated grains. Aperture on a produced neck that consists of much finer agglutinated grains than the chamber wall.

Remarks. Several good specimens were found in Holes U1343A and U1344B. In the North Atlantic, Reophax bilocularis has a habit of picking up small planktonic foraminiferal tests in addition to mineral grains. This feature is not observed in the specimens from the Bering Sea.

\section{Reophax bradyi Brönnimann \& Whittaker, 1980}

(Fig. 8:4a-b)

1980 Reophax bradyi Brönnimann \& Whittaker: 264, figs 13 - 16. 1994 Reophax bradyi Brönnimann \& Whittaker; Jones: 31, pl. 18, fig. 16; p. 37, pl. 30, fig. 12.

Description. Test free, uniserial, arched or slightly meandering, consisting of up to 5 chambers, increasing in size gradually. Chambers are round or slightly elongated. Wall very coarsely agglutinated, aperture terminal, without a neck.

Remarks. Schröder-Adams et al. (1990) illustrated specimens as $R$. scorpiurus from the Canadian Arctic that likely belong in this species.

\section{Reophax excentricus Cushman, 1910}

(Fig. 8:5, 8:6)

1910 Reophax excentricus Cushman: 92, fig. 134.

1939 Reophax excentricus Cushman; Cushman \& McCulloch: 60, pl. 3, figs $4-9$.

Description. Test fusiform, arched, with three chambers increasing rapidly in size. Wall coarsely agglutinated, of quartz and mafic grains. Aperture on a short neck, eccentrically placed on the last chamber.

Remarks. Reophax excentricus Cushman has its type locality from the stomachs of holothurians dredged at Albatross station D3603 in the Bering Sea at 1773 fathoms (Cushman 1910). This species is relatively common in the Pacific Ocean - it has also been reported off Oregon and the Alaskan Peninsula (Culver \& Buzas 1985) and characterizes depths of 200 - 2000 m off the Pacific coast of Central America (Culver \& Buzas 1987). It is regarded to be an opportunistic species (Kaminski et al. 1988).

\section{Reophax pilulifer Brady, 1884}

(Fig. 8:7)

1884 Reophax pilulifer Brady: 292, pl. 30, figs 18-20.

2005 Reophax pilulifer Brady; Kaminski \& Gradstein: 272, pl. 53, figs $1-9$ (fig. 1 is the lectotype). 

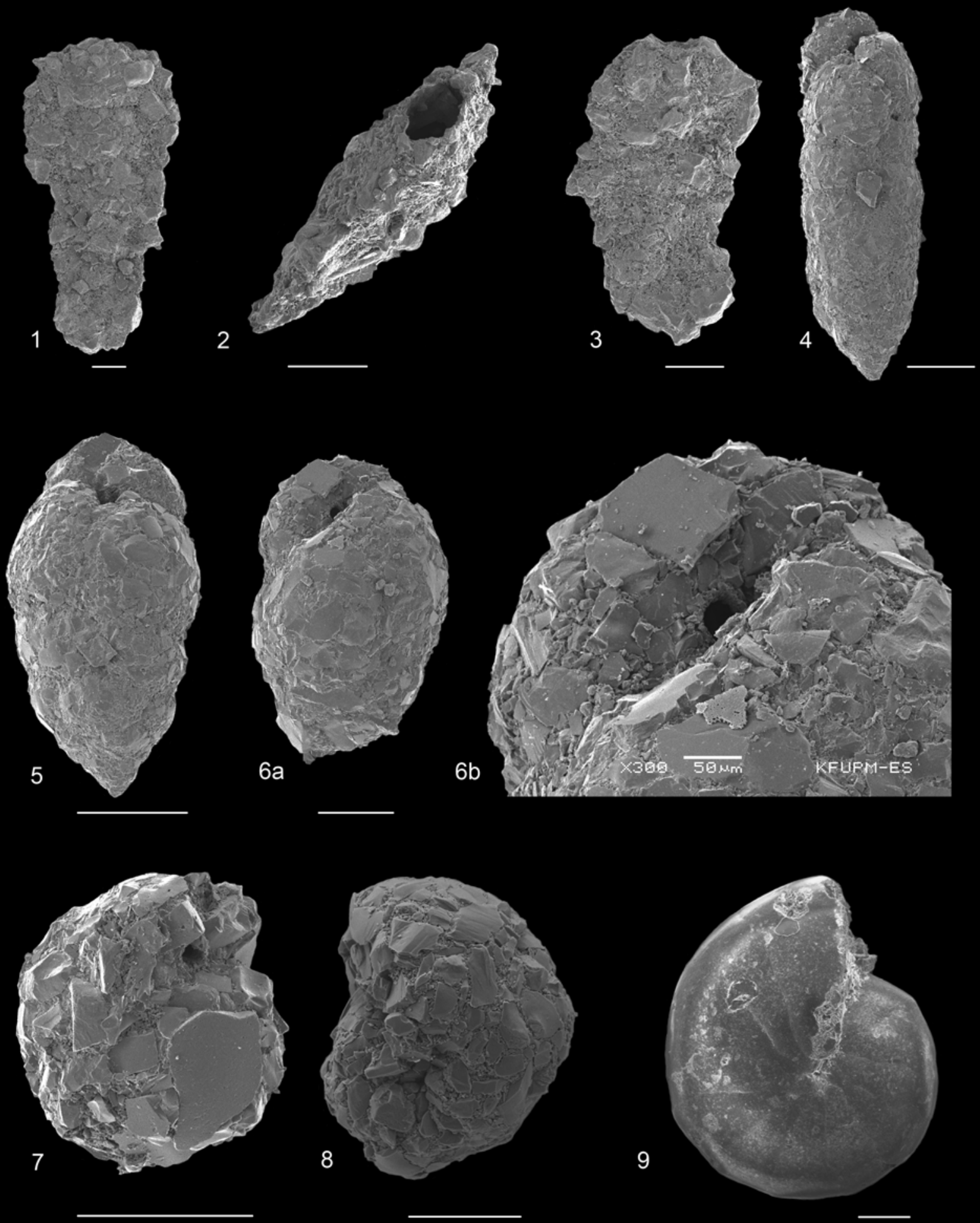

Fig. 9. (1 - 3) Glaphyrammina cf. americana (Cushman, 1910), Hole U1344B. (4-6b) Eggerelloides sp. 1, Hole U1345C. (7, 8) Recurvoides sp.: 7, Hole U1343E; 8, Hole U1345B. (9) Cyclammina compressa Cushman, 1917, Hole U1342A. Scale bar $200 \mu$ m unless labelled otherwise.

Description. Test robust, straight or curved, with 3 to 5 rapidly enlarging chambers. Chambers are globular and only slightly envelop preceding chambers. Wall coarse, comprised of a single layer of large sand grains in a matrix of finer grains, with organic cement. Aperture a round opening, situated on a low apertural shoulder, but without a neck.
Remarks. Kaminski \& Gradstein (2005) designated a lectotype from the Carpenter Collection in the NHM, London. The type locality is Porcupine Station 31 in the North Atlantic, 1360 fathoms water depth. Cushman (1921) recorded it from 13 Albatross stations in the Philippine Sea between 208 and 1560 fathoms, but noted that these specimens are smaller than Atlantic specimens and 'are not 


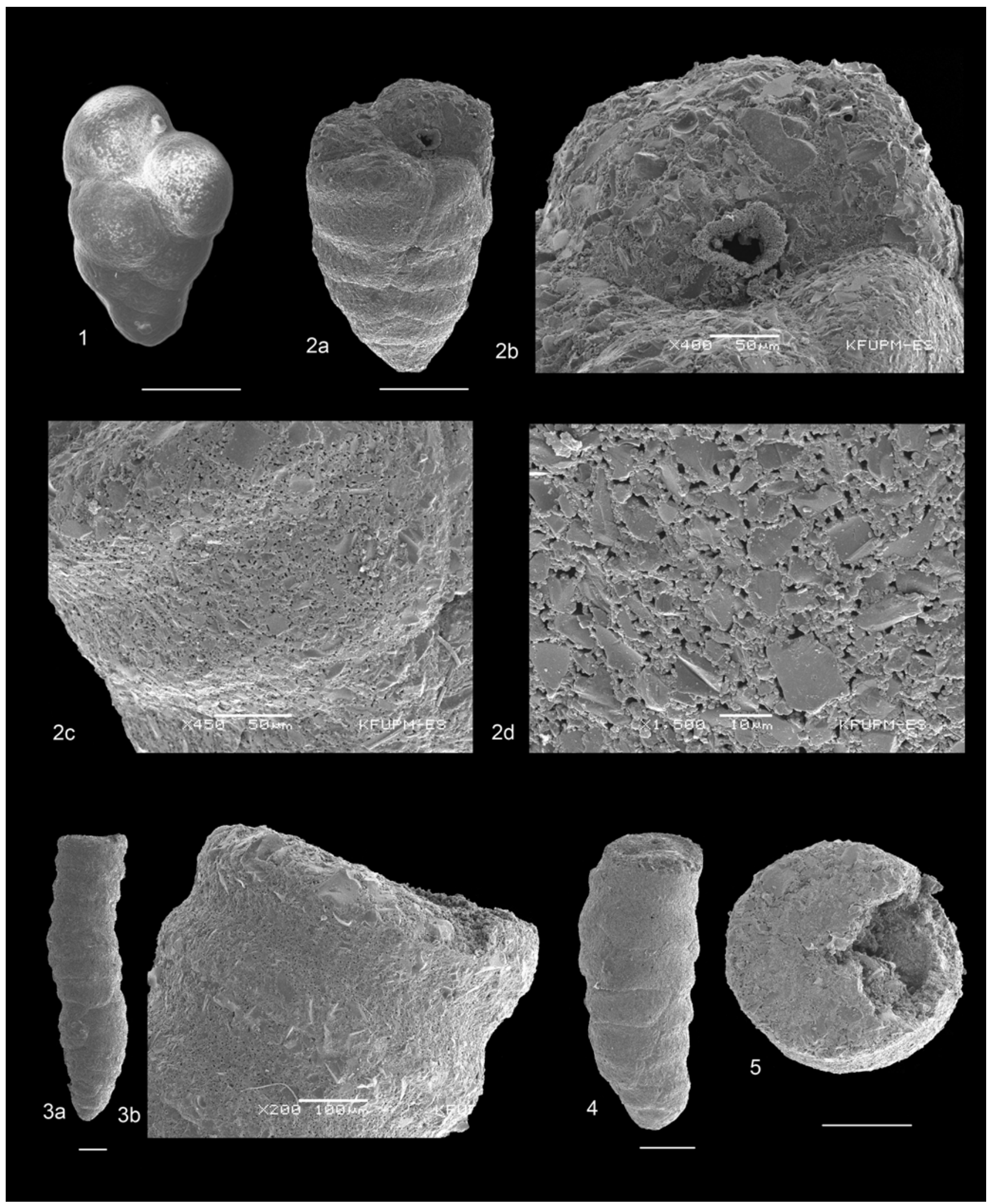

Fig. 10. (1) Karreriella sp. 1, Hole U1341B. (2a-5) Martinottiella sp. 3, Hole U1342A. Scale bar $200 \mu \mathrm{m}$ unless labelled otherwise.

typical'. Specimens from the Bering Sea are smaller than the types, and are coarsely agglutinated. Large concentrations of $R$. pilulifer were observed in the St Anne Trough, Kara Sea, Siberian Arctic (Korsun et al. 1988).

Reophax scorpiurus de Montfort, 1808 (not figured)
1808 Reophax scorpiurus de Montfort: 331, text-fig. 130. 1980 Reophax scorpiurus de Montfort; Brönnimann \& Whittaker: 261, figs $1-7,12,17$ (figs 2, 5 show the neotype).

Remarks. Smaller than most other species, it displays a characteristic arched test and elongated final chamber, with a 
produced aperture. Brönnimann \& Whittaker (1980) designated a neotype for $R$. scorpiurus from the SE Adriatic. The neotype and paraneotypes are from a shallow-water sample collected by H. Sidebottom off Corfu, and are preserved in the collections of the NHM, London in slide ZF3985.

\section{Reophax spiculifer Brady, 1879}

(Fig. 8:8)

1879 Reophax spiculifera Brady: 54, pl. 4, figs 10-11.

1994 Reophax spiculifer Brady; Jones: 38, pl. 31, figs 16-17.

Description. Test slender, uniserial and rectilinear. Chambers are strongly elongated and taper toward the aperture. Wall comprised of quartz grains and fragments of sponge spicules that are aligned subparallel to the long axis of the test. Spicules do not protrude from the chambers. Aperture terminal, round, without a neck.

Remarks. In his description of the species, Brady (1879, p. 55) remarked 'This is one of the many species of Foraminifera that give evidence of considerable selective power in respect to the material employed for the construction of their tests.' Specimens from Hole U1344D display a greater admixture of mineral grains in the test wall, but are otherwise similar to Brady's specimens.

\section{Reophax sp. 2 'tufty spicules'}

(Fig. 8:9)

Remarks. Broken fragments of a Reophax species that agglutinates numerous sponge spicules more or less normal to the test surface were found in Hole U1341A. The morphology of the whole specimen is unknown.

\section{Genus Evolutinella Mjatliuk, 1971} Evolutinella rotulata (Brady, 1881)
(not figured)

1881 Haplophragmium rotulatum Brady: 50.

1994 Evolutinella rotulata (Brady); Jones: 40, pl. 34, figs 5-6.

Remarks. A single specimen was found in Hole U1340A.

Genus Veleroninoides Saidova, 1981

Veleroninoides scitulus (Brady, 1881)

(Fig. 8:10)

1881 Haplophragmium scitulum Brady: 50.

1884 Haplophragmium scitulum Brady; Brady: 308, pl. 34, figs $11-13$.

1994 Veleroninoides scitulus (Brady); Jones: 41, pl. 34, figs 11 - 13.

Description. Test planispiral, biumbilicate, evolute with deep umbilici, with numerous low chambers in about two to three whorls, increasing very little in size as added. Periphery broadly rounded, margins slightly lobulate, with chambers wider than high when viewed from the periphery. Later sutures slightly depressed, nearly radial. Wall medium-finely agglutinated, surface smoothly finished. Aperture interio-areal, a low oval to elliptical opening near the base of the apertural face, bordered by a thin lip.

Remarks. The type specimens of $V$. scitulus in the Brady Collection are from 'Knight Errant' Station 7 at 530 fathoms in the Faroe
Channel. Our specimens from the Bering Sea are smaller and more coarsely agglutinated than the type specimens.

Genus Glaphyrammina Loeblich \& Tappan, 1984

Glaphyrammina cf. americana (Cushman, 1910) (Figs 8:11a, b and 9:1-9:3)

1910 Ammobaculites americanus Cushman: 117, text-figs 184-185. 1994 Glaphyrammina americana (Cushman); Jones: 40, pl. 34, figs $1-4$.

Description. Test free, broad and flattened, thin and fragile. Early portion planispirally enrolled and partially to completely evolute, sutures poorly visible, later portion uncoiled and may have a few rectilinear chambers with horizontal depressed sutures. Wall coarsely agglutinated, with larger grains in a groundmass of smaller grains. Larger pointed quartz grains project out from the periphery in the coiled portion of the test. Aperture a terminal elongate narrow opening, extending across nearly the breadth of the chamber, not produced.

Remarks. Loeblich \& Tappan (1984) remarked that sutures in Glaphyrammina may simply represent external indication of periodic growth, as the interior is hollow and undivided by septa, possibly with organic partitions. The holotype of Ammobaculites americanus Cushman, 1910 is from Albatross Station 3419, collected at 772 fathoms off the west coast of Mexico. Our specimens differ from Cushman's types in possessing a well-developed uniserial portion and a very coarsely agglutinated test with the odd larger mafic grain embedded in the wall, making it difficult to observe the sutures. This species is common in Hole U1344B.

Genus Cribrostomoides Cushman, 1910

Cribrostomoides subglobosus (Cushman, 1910) (not figured)

1910 Haplophragmoides subglobosum (M. Sars); Cushman: 105, text-figs $162-164$.

1994 Cribrostomoides subglobosus (Cushman); Jones: 40, pl. 34, figs $11-13$.

2005 Cribrostomoides subglobosus (Cushman); Kaminski \& Gradstein: 392, text-fig 92 (lectotype), pl. 92, figs 1a-3b.

Remarks. The correct citation of the authorship of this species was discussed by Kaminski \& Gradstein (2005), who provided a detailed description. A rather coarsely agglutinated variety of this species was observed in Hole U1343C.

Genus Recurvoides Earland, 1934

$$
\text { Recurvoides sp. }
$$

(Fig. 9:7, 9:8)

Remarks. A small, almost spherical, coarsely agglutinated species of Recurvoides with a round to oval aperture in the lower part of the apertural face.

\author{
Genus Eggerelloides Haynes, 1973 \\ Eggerelloides sp. 1 \\ (Fig. 9:4-9:6b)
}

Description. Test elongate, fusiform, initially coiled in a high trochospire of about 5 whorls with four chambers per whorl, then 
reducing to three chambers per whorl. Chambers are somewhat inflated, sutures depressed. Wall is made of fine quartz with occasional larger grains, with orange-brown organic cement. The initial part of the test has a more intense colour owing to the abundance of organic cement. Aperture a high interiomarginal arch, umbilical in position, surrounded by a thin lip.

Remarks. We place this species into Eggerelloides based on its high, loop-shaped aperture, though its internal structure (or toothplate) was not observed. Rhumblerella differs in possessing a low interiomarginal aperture. The North Pacific form of Eggerelloides advena (Cushman), as depicted by Tsujimoto et al. (2006) and by Vázquez Riveiros \& Patterson (2007), differs in possessing a slender test and more well-developed triserial part. In our samples, the species is most abundant at Site U1345.

Genus Cyclammina Brady, 1879

Cyclammina compressa Cushman, 1917 (Fig. 9:9)

1917 Cyclammina compressa Cushman: 653.

1921 Cyclammina compressa Cushman; Cushman: 85, pl. 16, figs $2 \mathrm{a}, \mathrm{b}$.

Description. Test small for the genus, coiling planispiral, involute, with $12-13$ chambers in the final whorl. Sutures radial, nearly straight, depressed slightly. Umbilicus flush or only depressed slightly. Periphery subacute. Wall consisting of an inner alveolar layer and a much thinner imperforate epidermal (outermost) layer, finely agglutinated with a smooth finish. Alveoles are unidimensional and equally spaced on the outer chamber wall. Aperture a broad interiomarginal slit with a thin upper lip of finely agglutinated particles. Areal supplementary apertures are not observed and, if present, are only small openings between the larger agglutinated grains in the apertural face.

Remarks. Cushman (1917, 1921) differentiated Cyclammina compressa from $C$. cancellata Brady by its smaller size, open and depressed umbilicus, evolute coiling and acute periphery. The syntypes preserved in the Cushman Collection (CC420) are from Albatross Station 5470, east of Luzon, at 540 fathoms. The specimens are over $3 \mathrm{~mm}$ in diameter, and have an average of 14 chambers in the final whorl. Banner (1970) regarded this species to be conspecific with $C$. cancellata Brady based on the structure of the hypodermis and alveoles. Kaminski \& Gradstein (2005) accepted Banner's synonymy of the two species.

In the Bering Sea, typical Cyclammina cancellata has not been found - the specimens recovered in Hole U1343A are best ascribed to $C$. compressa, which differs from typical Cyclammina cancellata in its smaller dimensions, more compressed lateral sides, straighter sutures and in lacking distinct supplementary areal apertures. The Bering Sea specimens are even smaller than Cushman's specimens from the Philippines, and do not have any visible areal supplementary apertures, whereas these are visible in Cushman's (1921) illustrations. Additionally, the umbilicus is not as depressed as Cushman depicted it. Cushman (1921, p. 86) remarked: 'This species seems to be in deeper and colder water than the preceding [C. cancellata]'.

Genus Karreriella Cushman, 1933

\section{Karreriella sp. 1}

(Fig. 10:1)

2013 Karreriella sp. 1; Kaminski et al.: 339, fig. 3a-f.
Description. Test free, elongate, initially trochospiral with up to five chambers per whorl, later reduced to twisted triserial and finally becoming biserial in just the final one or two pairs of chambers. Chambers in the terminal biserial part are globular, with depressed sutures. Wall finely agglutinated, with a smooth outer surface. Aperture areal, a rounded opening slightly above the base of the apertural face in the triserial stage, becoming more areal and increasingly oval in the biserial adult stage, produced and surrounded by a distinct lip.

Remarks. A single specimen was found in Hole U1341B. It most closely resembles the species described as 'Karreriella sp. 1' by Kaminski et al. (2013) from the Pliocene of Hole U1341B.

Genus Martinottiella Cushman, 1933

\section{Martinottiella sp. 3}

(Fig. 10:2-10:5)

Description. Test elongate, cylindrical, initial $6-7$ whorls coiled in a high trochospire with four chambers per whorl, later reduced to uniserial. Wall finely agglutinated, canaliculate with pores open to the exterior. Aperture areal in the coiled stage, terminal and central in the uniserial stage, on a short tubular neck in the centre of the flattened terminal face.

Remarks. This species is common in the samples from Site U1342. It differs from the type species $M$. communis (d'Orbigny) in possessing open pores on the external chamber walls and a round (rather than oval or slit-like) aperture. The open pores are concentrated in the middle of the chamber wall - fewer pores are observed along the sutures (Fig. 10:3b). The apertural face in the adult stage is flat (Fig. 10:5).

\section{Acknowledgements and Funding}

We thank Kozo Takahashi, Ana Christina Ravelo and Carlos Alvarez Zarikian for the opportunity to participate in the IODP Expedition 323 scientific party, as well as the technical crew of the JOIDES Resolution. This work was partly funded by UK IODP (NERC grant NE/H003274/1 to SK). We are grateful for the support provided by King Abdulaziz City for Science and Technology through the Science and Technology Unit at King Fahd University of Petroleum \& Minerals for partially funding this work (project No. 11-ENV1613-04 to MAK) as part of the National Science, Technology, and Innovation Plan. We thank Robert Spielhagen (GEOMAR-Helmholtz Centre for Ocean Research), Claudia Cetean (Robertson International) and Eiichi Setoyama (Energy and Geoscience Institute, University of Utah) for comments on an early draft, and Sergei Korsun (P.P. Shirsov Institute of Oceanology) and Matias Reolid (University of Jaén) for helpful reviews. This is contribution no. 102 of the deep-water agglutinated foraminiferal project.

\section{Scientific editing by Laia Alegret}

\section{References}

Anderson, G.J. 1963. Distribution patterns of Recent foraminifera of the Bering Sea. Micropaleontology, 9, 305-317.

Arndt, S., Jørgensen, B.B., LaRowe, D.E., Middelburg, J.J., Pancost, R.D. \& Regnier, P. 2013. Quantifying the degradation of organic matter in marine sediments: A review and synthesis. Earth-Science Reviews, 123, 53-86.

Avnemelich, M. 1952. Revision of the tubular genera. Contributions from the Cushman Foundation for Foraminiferal Research, 3, 60-68.

Banner, F.T. 1970. A synopsis of the Spirocyclinidae. Revista Española de Micropalaeontologia, 2, 243-290.

Brady, H.B. 1879. Notes on some of the reticularian Rhizopoda of the 'CHALLENGER' Expedition Part I. On new or little known Arenaceous types. Quarterly Journal of Microscopical Sciences, 19, 20-67.

Brady, H.B. 1881. Notes on some of the reticularian Rhizopoda of the Challenger Expedition. Part III. 1. Classification. 2. Further notes on new species. 3. Note on Biloculina mud. Quarterly Journal of Microscopical Science, new series, 21, 31-71.

Brady, H.B. 1882. Report on the foraminifera. In: Tizard, T.G. \& Murray, J. (eds) Exploration of the Faröe Channel during the summer of 1880, in Her Majesty's hired ship 'Knight-Errant'. Proceedings of the Royal Society of Edinburgh, 11, 708-717. 
Brady, H.B. 1884. Report on the foraminifera dredged by H.M.S. CHALLENGER during the years 1873-1876. In: Murray, J. (ed.) Reports of the Scientific Results of the Voyage of the H.M.S. Challenger. Zoology, 9, 1-814.

Brönnimann, P. \& Whittaker, J.E. 1980. A revision of Reophax and its type species, with remarks on several other Recent hormosinid species (Protozoa: Foraminiferida) in the collections of the British Museum (Natural History). British Museum of Natural History (Zoology) Bulletin, 39, 259-272.

Bubenshchikova, N., Nürnberg, D., Lembke-Jene, L. \& Pavlova, G. 2008. Living benthic foraminifera of the Okhotsk Sea: Faunal composition, standing stocks and microhabitats. Marine Micropaleontology, 69, 314-333.

Carpenter, W.B. 1869. On the rhizopodal fauna of the deep sea. Proceedings of the Royal Society of London, 18, 59-62.

Coachman, L.K., Whitledge, T.E. \& Goering, J.J. 1999. Silica in Bering Sea deep and bottom water. In: Loughlin, T.R. \& Ohtani, K. (eds) Dynamics of the Bering Sea. North Pacific Marine Science Organization (PICES). University of Alaska, Fairbanks, 1-60.

Culver, S.J. \& Buzas, M.A. 1985. Distribution of Recent foraminifera off the North American Pacific coast from Oregon to Alaska. Smithsonian Contributions to the Marine Sciences, 26, 1-234.

Culver, S.J. \& Buzas, M.A. 1987. Distribution of Recent benthic Foraminifera off the Pacific coast of Mexico and Central America. Smithsonian Contributions to the Marine Sciences, 30, 1-184.

Cushman, J.A. 1910. A monograph of the foraminifera of the North Pacific Ocean. Part 1. Astrorhizidae and Lituolidae. United States National Museum Bulletin, 71, 1-134.

Cushman, J.A. 1913. New Textulariidae and other arenaceous foraminifera from the Philippine Islands and contiguous waters. Proceedings of the US National Museum, 44, 633-638

Cushman, J.A. 1917. New species and varieties of foraminifera from the Philipines and adjacent waters. Proceedings of the US National Museum, 51, 651-662.

Cushman, J.A. 1920. The foraminifera of the Atlantic Ocean. Part 2. Lituolidae. United States National Museum Bulletin, 104, 1-111.

Cushman, J.A. 1921. Foraminifera of the Philippine and adjacent seas. United States National Museum Bulletin, 100, 1-608.

Cushman, J.A. 1933. Some new foraminiferal genera. Contributions from the Cushman Laboratory for Foraminiferal Research, 9, 32-38.

Cushman, J.A. 1944. Foraminifera from the shallow water of the New England coast. Special Publication Cushman Laboratory for Foraminiferal Research, 12, 1-37.

Cushman, J.A. 1948. Arctic foraminifera. Contributions to the Cushman Laboratory for Foraminiferal Research Special Publication, 23, 1-79.

Cushman, J.A. \& McCulloch, I. 1939. A report on some arenaceous foraminifera. Allan Hancock Pacific Expeditions, 6, 1-113.

de Folin, L. 1887. Les Rhizopodes réticulaires. Naturaliste, Paris, série 2, 9, 102-103, 113-115.

de Montfort, D. 1808. Conchyliologie systematique et classification methodique de Coquilles. 1. Coquilles univalves, cloisonnées, Paris.

Earland, A. 1934. Foraminifera. Part III. The Falklands sector of the Antarctic (excluding South Georgia). Discovery Reports, 10, 1-208.

Echols, R.J. 1973. Foraminifera, Leg 19, Deep Sea Drilling Project. Initial Reports of the Deep Sea Drilling Project, 19, 721-735.

Eimer, G.H.T. \& Fickert, C. 1899. Die Artbildung und Verwandtschaft bei den Foraminiferen. Entwurf einer natürlichen Eintheilung der selben. Zeitschrift für Wissenschaftliche Zoologie, 65, 599-708

Expedition 323 Scientists 2010. Bering Sea palaeoceanography: PliocenePleistocene palaeoceanography and climate history of the Bering Sea. Integrated Ocean Drilling Program Preliminary Report, 323, http://doi.org/ 10.2204/iodp.pr.323.2010

Expedition 323 Scientists 2011. Expedition 323 summary. In: Takahashi, K. Ravelo, A.C. \& Alvarez Zarikian, C.A., Expedition 323 Scientists (eds) Proceedings of the Integrated Ocean Drilling Program, 323. IODP Management International, Inc., Tokyo, http://doi.org/10.2204/iodp.proc. 323.106.2011

Flint, J.M. 1899. Recent foraminifera, a descriptive catalogue of specimens dredged by the U.S. Fish Commission steamer Alabatross. Annual Report (1897). US National Museum.

Gooday, A.J. 1988a. The genus Bathysiphon (Protista, Foraminiferida) in the NE Atlantic: revision of some species described by de Folin (1886). Journal of Natural History, 22, 71-93.

Gooday, A.J. 1988b. The genus Bathysiphon (Protista, Foraminiferida) in the north-east Atlantic: a neotype for B. filiformis G.O. \& M. Sars, 1872 and the description of a new species. Journal of Natural History, 22, 95-105.

Gooday, A.J. \& Jorissen, F.J. 2012. Benthic foraminiferal biogeography: controls on global distribution patterns in deep-water settings. Annual Review of Marine Sciences, 4, 237-262

Gooday, A.J. \& Smart, C.W. 2000. Wall structure and test morphology in three large deep-sea agglutinated foraminifera, Rhabdammina parabyssorum Stschedrina, 1952, R. abyssorum Sars, 1869 and Astrorhiza granulosa (Brady, 1879) (Foraminiferida, Textulariina). In: Hart, M.B., Kaminski, M.A. \& Smart, C.W. (eds) Proceedings of the Fifth International Workshop on Agglutinated Foraminifera. Grzybowski Foundation Special Publication, 7, 105-115.

Gooday, A.J., Bernhard, J.M., Levin, L.A. \& Suhr, S.B. 2000. Foraminifera in the Arabian Sea oxygen minimum zone and other oxygen deficient settings: taxonomic composition, diversity, and relation to metazoan faunas. Deep-Sea Research II, 47, 25-54

Gooday, A.J., Hughes, J.A. \& Levin, L.A. 2001. The foraminiferan macrofauna from three North Carolina (U.S.A.) slope sites with contrasting carbon flux: a comparison with the metazoan macrofauna. Deep-Sea Research I, 48, 1709-1739.

Gooday, A.J., Bowser, S.S., Cedhagen, T., Cornelius, N., Hald, M., Korsun, S. \& Pawlowski, J. 2005. Monothalamous foraminiferans and gromiids (Protista) from western Svalbard: a preliminary survey. Marine Biology Research, 1 , 290-312.

Gradstein, F. \& Berggren, W.A. 1981. Flysch-type agglutinated foraminifera and the Maestrichtian to Palaeogene history of the Labrador and North Seas. Marine Micropaleontology, 6, 211-268.

Gradstein, F. \& Kaminski, M.A. 1989. Taxonomy and biostratigraphy of new and emended species of Cenozoic deep-water agglutinated foraminifera from the Labrador and North Seas. Micropaleontology, 35, 72-92.

Grzybowski, J. 1898. Otwornice pokładów naftonosnych okolicy Krosna. Rozprawy Wydzialu Matematyczno-Przyrodniczego, Akademia Umiejętności w Krakowie, (serya 2), 33, 257-305.

Hammer, Ø. \& Harper, D. 2006. Palaeontological Data Analysis. Blackwell, Oxford.

Hammer, Ø., Harper, D. \& Ryan, P.D. 2005. PAST: Palaeontological statistics soft package for education and data analysis. Palaeontologica Electronica, 4, $1-9$

Haynes, J.R. 1973. Cardigan Bay Recent Foraminifera (Cruises of the R.V Antur, 1962-1964). Bulletin of the British Natural History Museum, Zoology, Suppl. 4, 1-245.

Hayward, B.W., Grenfell, H.R., Carter, R. \& Hayward, J.J. 2001. Depth distribution of Recent deep-sea benthic foraminifera east of New Zealand, and their potential for improving palaeobathymetric assessments of Neogene microfaunas. New Zealand Journal of Geology and Geophysics, 44, 555-587.

Hermelin, J.O.R. \& Shimmield, G.B. 1990. The importance of the oxygen minimum zone and sediment geochemistry in the distribution of Recent benthic foraminifera in the northwest Indian Ocean. Marine Geology, 91, 1-29.

Hofmann, M. \& Schellnhuber, H-J. 2009. Ocean acidification affects marine carbon pump and triggers extended marine oxygen holes. Proceedings of the National Academy of Sciences USA, 106, 3017-3022.

Holbourn, A., Henderson, A.S. \& Macleod, N. 2013. Atlas of Benthic Foraminifera. Wiley-Blackwell, Oxford.

Jian, Z., Wang, L., Kienast, M., Sarnthein, M., Kuhnt, W., Lin, H.L. \& Wang, P. 1999. Benthic foraminiferal palaeoceanography of the South China Sea over the last 40,000 years. Marine Geology, 156, 159-186.

Jones, R.W. 1994. The Challenger Foraminifera. Oxford University Press, Oxford

Jones, R.W. \& Charnock, M.A. 1985. 'Morphogroups' of agglutinating foraminifera. Their life positions and feeding habits and potential applicability in (palaeo)ecological studies. Revue de Palaeobiologie, 4, 311-320.

Jorissen, F.J., De Stigter, H.C. \& Widmark, J.G.V. 1995. A conceptual model explaining benthic foraminiferal microhabitats. Marine Micropaleontology, 22, 3-15.

Jorissen, F.J., Fontanier, C. \& Thomas, E. 2007. Palaeoceanographical proxies based on deep-sea benthic foraminiferal assemblage characteristics. In Hillaire-Marcel, C. \& de Vernal, A. (eds) Proxies in Late Cenozoic Palaeoceanography: Pt. 2: Biological Tracers and Biomarkers. Elsevier, Amsterdam, 263-326.

Kaiho, K. 1999. Effect of organic carbon flux and dissolved oxygen on the benthic foraminiferal oxygen index (BFOI). Marine Micropaleontology, 37, 67-76.

Kaminski, M.A. 2014. The year 2010 classification of the agglutinated foraminifera. Micropaleontology, 61, 89-108.

Kaminski, M.A. \& Austin, W.E.N. 1999. Oligocene deep-water agglutinated foraminifers at Site 985, Norwegian Basin, southern Norwegian Sea Proceedings of the ODP, Scientific Results, 162. Ocean Drilling Program, College Station, TX, 169-177.

Kaminski, M.A. \& Cetean, C.G. 2011. Lectotypes of type species of agglutinated foraminiferal genera in the collections of the Natural History Museum, London. Part 2. Hippocrepinina and Hormosinina. In: Kaminski, M.A. \& Filipescu, S. (eds) Proceedings of the Eighth International Workshop on Agglutinated Foraminifera. Grzybowski Foundation Special Publications, 16, 61-69.

Kaminski, M.A. \& Geroch, S. 1993. A revision of foraminiferal species in the Grzybowski Collection. In: Kaminski, M.A., Geroch, S. \& Kaminski, D. (eds) The Origins of Applied Micropalaeontology: The School of Jozef Grzybowski. Grzybowski Foundation Special Publication, 1, 239-323.

Kaminski, M.A. \& Gradstein, F.M. 2005. Atlas of Paleogene cosmopolitan deepwater agglutinated foraminifera. Grzybowski Foundation Special Publication, 10, 1-547.

Kaminski, M.A., Grassle, J.F. \& Whitlatch, R.D. 1988. Life history and recolonization among agglutinated foraminifera in the Panama Basin Proceedings of the Second Workshop on Agglutinated Foraminifera, Vienna Austria, June 23-26, 1986. Abhandlungen der geologischen Bundesanstalt, Wien, 41, 228-244.

Kaminski, M.A., Boersma, A., Tyszka, J. \& Holbourn, A.E.L., 1995. Response of deep-water agglutinated foraminifera to dysoxic conditions in the California borderland basins. In: Kaminski, M.A., Geroch, S. \& Gasinski, M.A. (eds) Proceedings of the Fourth International Workshop on Agglutinated Foraminifera. Grzybowski Foundation Special Publication, 3, 131-140. 
Kaminski, M.A., Silye, L. \& Kender, S. 2005. Miocene deep-water agglutinated foraminifera from ODP Hole 909c: Implications for the palaeoceanography of the Fram Strait Area, Greenland Sea. Micropaleontology, 51, 373-403.

Kaminski, M.A., Cetean, C. \& Henderson, A.S. 2008. Lectotypes of type species of agglutinated foraminiferal genera in the collections of the Natural History Museum, London. Part 1. Astrorhizina and Saccamminina. In: Kaminski, M. A. \& Coccioni, R. (eds) Proceedings of the Seventh International Workshop on Agglutinated Foraminifera. Grzybowski Foundation Special Publication, 13, 63-77.

Kaminski, M.A., Kender, S., Ciurej, A., Balc, R. \& Setoyama, E. 2013. Pliocene agglutinated benthic foraminifera from Site U1341 in the Bering Sea (IODP Expedition 323). Geological Quarterly, 57, 335-342.

Kender, S., Kaminski, M.A. \& Cieszkowski, M. 2005. Foraminifera from the Eocene Variegated Shales near Barwinek (Magura Unit, Outer Carpathians) the type locality of Noth (1912) revisited. Annales Societatis Geologorum Poloniae, 75, 249-271.

Kender, S., Kaminski, M.A. \& Jones, R.W. 2008a. Oligocene deepwater agglutinated foraminifera from the Congo Fan, Offshore Angola: Palaeoenvironments and assemblage distributions. In: Kaminski, M.A. \& Coccioni, R. (eds) Proceedings of the Seventh International Workshop on Agglutinated Foraminifera. Grzybowski Foundation Special Publication, 13 107-156.

Kender, S., Kaminski, M.A. \& Jones, R.W. 2008b. Early to Middle Miocene foraminifera from the deep-sea Congo Fan, offshore Angola Micropaleontology, 55, 477-568.

Khusid, T.A., Basov, I.A., Gorbarenko, S.A. \& Chekhovskaya, M.P. 2006. Benthic foraminifers in upper Quaternary sediments of the southern Bering Sea: Distribution and palaeoceanographic interpretations. Stratigraphy and Geological Correlation (English edn), 14, 538-548.

Korsun, S., Hald, M., Panteleeva, N. \& Tarasov, G. 1988. Biomass of foraminifera in the St. Anna Trough, Russian Arctic Continental Margin. Sarsia, 83, 419-431.

Levin, L.A., Etter, R.J. et al. 2001. Environmental influences on regional deep-sea species diversity. Annual Review of Ecology and Systematics, 32, 51-93.

Loeblich, A.R., Jr \& Tappan, H. 1984. Some new proteinaceous and agglutinated genera of Foraminiferida. Journal of Paleontology, 58, 1158-1163.

Loeblich, A.R., Jr \& Tappan, H. 1987. Foraminiferal genera and their classification. Van Nostrand Reinhold, New York.

Lukina, T. 2001. Foraminifera of the Laptev Sea. Protistology, 2, 105-122.

Majewski, W. 2005. Benthic foraminiferal communities: distribution and ecology in Admiralty Bay, King George Island, West Antarctica. Polish Polar Research, 26, 159-214.

Matoba, Y. \& Fukusawa, K. 1992. Depth distribution of Recent benthic foraminifera on the continental shelf and uppermost slope off southern Akita Prefecture, northeast Japan (the Eastern Japan Sea). In: Ishizaki, K. \& Saito, T. (eds) Centenary of Japanese Micropaleontology, Terra Scientific Publishing Company, Tokyo, 207-226.

Mjatliuk, E.V. 1971. K sistematike spiral'noploskostnykh predstaviteley Khaplofragmoidid (Foraminifery) [On the systematics of planispiral representatives of the Haplophragmoididae (Foraminifera)]. Trudy Vsesoyuznogo Neftyanogo Nauchno-issledovatel'skogo Geologo-razvedochnogo Instituta (VNIGRI), 291, 18-25.

Moffitt, S.E., Hill, T.M., Ohkushi, K., Kennett, J.P. \& Behl, R.J. 2014 Vertical oxygen minimum zone oscillations since $20 \mathrm{ka}$ in Santa Barbara Basin: A benthic foraminiferal community perspective. Paleoceanography, 29, 44-57.

Nagy, J. 1992. Environmental significance of foraminiferal morphogroups in Jurassic North Sea deltas. Palaeogeography, Palaeoclimatology, Palaeoecology, 95, 111-1340.

Nagy, J., Reolid, M. \& Rodriguez-Tovar, F.J. 2009. Foraminiferal morphogroups in dysoxic shelf deposits from the Jurassic of Spitsbergen. Polar Research, $\mathbf{2 8}$ 214-221.

Nikitenko, B.L., Reolid, M. \& Glinskikh, L. 2013. Ecostratigraphy of benthic foraminifera for interpreting Arctic record of Early Toarcian biotic crisis (Northern Siberia, Russia). Palaeogeography Palaeoclimatology Palaeoecology, 376, 200-212.

Norman, A.M. 1878. On the genus Haliphysema with a description of several forms apparently allied to it. Annals and Magazine of Natural History, series $5,1,265-284$

Pawlowski, J., Bolivar, S.S., Fahrni, J., de Vargas, C., Gouy, M. \& Zaninetti, L. 1997. Extreme differences in rates of molecular evolution of foraminifera revealed by comparison of ribosomal DNA sequences and the fossil record. Molecular Biology and Evolution, 14, 498-505.

Pawlowski, J., Holzmann, M. \& Tyszka, J. 2013. New supraordinal classification of Foraminifera: molecules meet morphology. Marine Micropaleontology, 100, $1-10$

Pflaumann, U. 1964. Geologisch-mikropaläontologische Untersuchungen in der Flysch-Oberkreide zwischen Wertach und Chimsee in Bayern. Inauguraldissertation der Hohen Naturwissenschaftlichen Facultät der Ludwig-Maximilians-Universität zu München, 1-180.

Pfleger, F.B. 1952. Foraminifera distribution in some sediment samples from the Canadian and Greenland Arctic. Contributions from the Cushman Foundation for Foraminiferal Research, 3, 80-89.
Reuss, A.E. 1862. Entwurf einer systematischen Zussammenstellung der Foraminiferen. Sitzungbericht der Kaiserlichen Akademie der Wissenschaften in Wien, Mathematisch-Naturwissenschaftliche Classe (1861), 44, 355-396.

Rhumbler, L. 1895. Entwurf eines naturlichen Systems Der Thalamophoren. Nachrichten von der Gesellschaft der Wissenschaften zu Göttingen, Math.Physik. Klasse, 1895, 51-98.

Rhumbler, L. 1911. Die Foraminiferen (Thalamophoren) der PlanktonExpedition. Erster Teil, Die allgemeinen Organizationsverhaltnisse der Foraminiferen. Ergebnisse der Plankton-Expedition der Humboldt-Stiftung, Kiel. Leipzig, Bd. 3 L. C. (1909), 1-331.

Saidova, Kh.M. 1970. Benthic foraminifera in the Kurile-Kamchatka region based on the data of the 39th cruise of the R/V 'Vityaz'. Trudy Instituta Okeanologii, 86, 134-161.

Saidova, Kh.M. 1975. Benthonic foraminifera of the Pacific Ocean. Academy of Sciences of the USSR, P.P. Shirshov Institute of Oceanology, Moscow.

Saidova, Kh.M. 1981. O sovremennom sostoyanii sistemy nadvidovykh taksonov Kaynozoyskikh bentosnykh foraminifer [On an up-to-date system of supraspecific taxonomy of Cenozoic benthonic foraminifera]. Institut Okeanologii, P.P. Shirshova, Akademiya Nauk SSSR, Moscow, 1-73.

Sambrotto, R.N., Goering, J.J. \& McRoy, C.P. 1984. Large yearly production of phytoplankton in the western Bering Strait. Science, 225, 1147-1150.

Sandahl, O. 1858. Tvånya former af Rhizopoder. Öfversigt af. K. VetenskapsAkademien Förhandlingar Stockholm (1857), 14, 299-303.

Sars, G.O. 1872. Undesøgelser over Hardangerfjordens Fauna. Forhandlinger $i$ Videnskasselskabet $i$ Kristiana, 1871, 246-255.

Schlitzer, R. 2000. Electronic Atlas of WOCE Hydrographic and Tracer Data Now Available. EOS Transactions of the $A G U, \mathbf{8 1}, 45$

Schröder, C.J. 1986. Deep-water arenaceous foraminifera in the Northwest Atlantic Ocean. Canadian Technical Report of Hydrography and Ocean Sciences, 71, 191

Schröder-Adams, C.J., Cole, F.E., Medioli, F.S., Mudie, P.J., Scott, D.B. \& Dobbin, L. 1990. Recent Arctic shelf foraminifera: seasonally ice covered vs. perennially ice covered areas. Journal of Foraminiferal Research, 20, 8-36.

Schultze, F.E. 1875. Zoologische Ergebnisse der Nordseefart vom 21 Juli bis 9 September 1872; 1. Rhizopoden. Commission der Wissenschaftliche Untersuchung Deutschlands Meere von Kiel, Jahresberichte. Berlin, Deutschland, 1875, Jahrg. 2-3.

Schumacher, S., Jorissen, F.J., Dissard, D., Larkin, K.E. \& Gooday, A.J. 2007. Live (Rose Bengal stained) and dead benthic foraminifera from the oxygen minimum zone of the Pakistan continental margin (Arabian Sea). Marine Micropaleontology, 62, 45-73.

Sen Gupta, B.K. \& Machain-Castillo, M.L. 1993. Benthic foraminifera in oxygen-poor habitats. Marine Micropaleontology, 20, 18-201.

Setoyama, E. \& Kaminski, M.A. 2015. Neogene benthic foraminifera from the southern Bering Sea (IODP Expedition 323). Palaeontologia Electronica, 18, $38 \mathrm{~A}$

Setoyama, E., Kaminski, M.A. \& Tyszka, J. 2011. The Late Cretaceous-Early Palaeocene palaeobathymetric trends in the southwestern Barents Sea Palaeoenvironmental implications of benthic foraminiferal assemblage analysis. Palaeogeography, Palaeoclimatology, Palaeoecology, 307, 44-58.

Springer, A.M., McRoy, C.P. \& Flint, M.V. 1996. The Bering Sea Green Belt: shelf-edge processes and ecosystem production. Fisheries Oceanography, 5, 205-223.

Stabeno, P.J., Schumacher, J.D. \& Ohtani, K. 1999. The physical oceanography of the Bering Sea. In: Loughlin, T.R. \& Ohtani, K. (eds) Dynamics of the Bering Sea. University of Alaska Sea Grant, Fairbanks, 1-28.

Stramma, L., Johnson, G.C., Sprintall, J. \& Mohrholz, V. 2008. Expanding Oxygen Minimum Zones in the tropical oceans. Science, 320, 655-658.

Stramma, L., Schmidtko, S., Levin, L.A. \& Johnson, G.C. 2010. Ocean oxygen minima expansions and their biological impacts. Deep-Sea Research I, 57, $587-595$

Stschedrina, Z.G. 1969. O nekotorykh izmeneniyakh v sisteme semeystv Astrorhizidae i Reophacidae (Foraminifera) [On some changes in the systematics of the families Astrorhizidae and Reophacidae (Foraminifera)]. Voprosy Mikropaleontologii, 11, 157-170.

Sun, X., Corliss, B.H., Brown, C.W. \& Showers, W.J. 2006. The effect of primary productivity and seasonality on the distribution of deep-sea benthic foraminifera in the North Atlantic. Dee-Sea Research I, 53, $28-47$.

Tsujimoto, A., Nomura, R., Yasuhara, M. \& Yoshikawa, S. 2006. Benthic foraminiferal assemblages in Osaka Bay, southwestern Japan: faunal changes over the last 50 years. Palaeontological Research, 10, 141-161.

van den Akker, T.J.H.A., Kaminski, M.A., Gradstein, F.M. \& Wood, J. 2000 Campanian to Palaeocene biostratigraphy and palaeoenvironments in the Foula Sub-basin, west of the Shetland Islands, UK. Journal of Micropalaeontology, 19, 23-43, http://doi.org/10.1144/jm.19.1.23

Vázquez Riveiros, N. \& Patterson, R.T. 2007. An illustrated guide to fjord foraminifera from the Seymour-Belize Inlet Complex, Northern British Columbia, Canada. Palaeontologia Electronica, 11, 1-45.

Vilks, G. 1969. Recent foraminifera in the Canadian Arctic. Micropaleontology, 15, 35-60.

Warner, M.J \& Roden, G.I. 1995. Chlorofluorocarbon evidence for recent ventilation of the deep Bering Sea. Nature, 373, 409-412. 
Waskowska-Oliwa, A. 2008. The Palaeocene assemblages of agglutinated foraminifera from deep-water basinal sediments of the Carpathians (Subsilesian Unit, Poland): biostratigraphical remarks. In: Kaminski, M.A. \& Coccioni, R. (eds) Proceedings of the Seventh International Workshop on Agglutinated Foraminifera. Grzybowski Foundation Special Publication, 13, 227-265.

Wollenburg, J. 1992. Zur Taxonomie von rezenten bentischen Foraminiferen aus dem Nansen Becken, Arktischer Ozean. Berichte der Polarforschung 112. Alfred Wegener Institute for Polar and Marine Research, Bremerhaven.
Wollenburg, J. 1995. Benthische Foraminiferenfaunen als WassermassProduktions- und Eisdriftanzeiger im Arktischen Ozean. Berichte zur Polarforschung 179. Alfred Wegener Institute for Polar and Marine Research, Bremerhaven.

Wright, T.S. 1861. Observations on British Protozoa and Zoophytes. Annals and Magazine of Natural History, series 3, 8, 120-135.

Zheng, S.Y. \& Fu, Z.X. 2001. Fauna Sinica, Phylum Granuloreticulosa, Class Foraminiferea, Agglutinated Foraminifera. Science Press, Beijing. 